\title{
THE EFFECTS OF DNA DATABASES ON CRIME*
}

\author{
Jennifer L. Doleac ${ }^{\dagger}$
}

December 2, 2012

Working Paper

\begin{abstract}
Since 1988, every US state has established a database of criminal offenders' DNA profiles. These databases have received widespread attention in the media and popular culture, but this paper provides the first rigorous analysis of their impact on crime. DNA databases are distinctive for two reasons: (1) They exhibit enormous returns to scale, and (2) they work mainly by increasing the probability that a criminal is punished rather than the severity of the punishment. I exploit the details and timing of state DNA database expansions in two ways, first to address the effects of DNA profiling on individuals' subsequent criminal behavior and then to address the impacts on crime rates and arrest probabilities. I first show that profiled violent offenders are more likely to return to prison than similar, unprofiled offenders. This suggests that the higher probability of getting caught outweighs the deterrent effect of DNA profiling. I then show that larger DNA databases reduce crime rates, especially in categories where forensic evidence is likely to be collected at the scene-e.g., murder, rape, assault, and vehicle theft. The probability of arresting a suspect in new crimes falls as databases grow, likely due to selection effects. Back-of-the-envelope estimates of the marginal cost of preventing each crime suggest that DNA databases are much more cost-effective than other common law enforcement tools.
\end{abstract}

JEL Classifications: K14, K42, H07

\footnotetext{
*I am grateful to Ran Abramitzky, B. Douglas Bernheim, David Bjerk, William Evans, Leora Friedberg, William Gale, Brandon Garrett, Caroline Hoxby, Ilyana Kuziemko, Jonathan Meer, Nicholas Sanders, and Kaitlin Shilling for helpful suggestions and comments. Thanks also to participants in seminars at the American Enterprise Institute, the Brookings Institution, the Harvard Kennedy School, the University of Maryland, the University of Notre Dame, Stanford University, the University of Virginia, and Wellesley College. I appreciate the financial support of the Hawley-Shoven Fellowship and the John M. Olin Program in Law and Economics, both at Stanford University.

${ }^{\dagger}$ Frank Batten School of Leadership and Public Policy, University of Virginia, Charlottesville, VA 22904. Email: jdoleac@virginia.edu.
} 


\section{Introduction}

\section{Introduction}

Beginning in 1988, states passed legislation to create (and subsequently expand) databases of criminal offenders' DNA profiles. The goal of cataloguing these genetic fingerprints was to quickly and accurately match known offenders with crime scene evidence. "Qualifying offenses"—-the types of offenses that qualify an offender for inclusion in the database-varied across states and expanded over time: Databases typically started with sex offenses, then added violent offenses and then non-violent crimes. Law enforcement officials made myriad promises about the crimereducing effects of this new tool, and its use has become widespread. The FBI currently links all states' databases to form the Combined DNA Index System (CODIS), which contained over 10 million offender profiles as of August 2011; this national database is well-known to the American public thanks to popular television shows like CSI. However, despite the financial and (potential) privacy costs of collecting and analyzing offenders' DNA samples, it is unclear whether the databases have had real benefits. This paper attempts to answer the following questions: How has DNA profiling impacted criminal behavior, and what are the general equilibrium effects on crime in the United States?

DNA profiling works by increasing the probability of conviction, conditional on offending, for individuals in the database. A rational offender should compare the expected benefit of committing a new offense to the expected cost, an increasing function of the probability of conviction and the (discounted) punishment he would receive. When the probability of conviction increases, some offenders will choose not to commit a new crime-this is the deterrent effect of the policy. Some offenders will decide to commit the crime anyway, and for them the higher probability of conviction means they're more likely to go to prison. While in prison, they will be physically prevented from committing additional crimes-this is the incapacitation effect. These effects should noticeably impact individuals' criminal records. Do they?

Directly comparing the behavior of profiled and unprofiled offenders is potentially problematic because, on average, profiled offenders have been convicted of more serious crimes than unprofiled offenders, and it would be difficult to credibly isolate the effect of DNA profiling from the effect of this underlying difference. Therefore, I use the effective dates of state database expansions as a source of exogenous variation in DNA profiling. Consider a state that expands its database to include all convicted and incarcerated burglars on date X. Convicted burglars released just after date $\mathrm{X}$ are added to the database, while those released just before date $\mathrm{X}$ are not. The two groups should be extremely similar in all other ways. In other words, there is a sharp discontinuity in the probability of being profiled (the "treatment") at date $\mathrm{X}$, but other characteristics that might affect recidivism risk do not change discontinuously at this thresh- 


\section{Introduction}

old. Using an indicator of whether a newly-qualifying offender was released post-expansion, I measure the effect of DNA profiling on observed recidivism.

Using information on expansion timing and criminal history data from seven states, I find significant effects of DNA profiling on observed recidivism within three years for a representative group of violent offenders: aggravated assault convicts. On average, DNA profiling has a large net probative effect - it helps identify suspects (as designed). In other words, profiled offenders continue to commit new offenses, but are caught much more often than those not in the database: They are $23.4 \%$ more likely to be convicted of another crime within three years than their unprofiled counterparts. The net probative effect is particularly large for offenders released before age 25, but is much smaller for those profiled after their first incarceration. To the extent that these differences stem from differences in deterrence, this suggests that collecting DNA from more offenders early in their criminal careers could deter even violent offenders from reoffending. Similar effects of DNA profiling are found on the probability of committing the most serious violent and property offenses.

These partial equilibrium results suggest that DNA profiling affects individuals' criminal trajectories, but the general equilibrium effect on crime is clearly of greater relevance for policymakers. Both deterrence and incapacitation should decrease the total amount of crime in each state, barring rapid replacement by new offenders. As more potential reoffenders are added to state DNA databases, the number of crimes should fall proportionally. Does it?

I note that OLS estimates of the effect of this variable on crime rates will be biased upwards because the number of profiles and number of crimes in a state are simultaneously determined. Also, state governments' adeptness and degree of motivation with regard to implementing database expansions affect the number of profiles uploaded. These state characteristics might also affect crime rates, resulting in omitted variable bias. I use an instrumental variable approach to substantially reduce these biases.

Specifically, I take advantage of the fact that DNA databases were generally expanded in response to widely-publicized "if only" cases: cases where a number of terrible crimes could have been prevented, or a wrongfully convicted person could have been exonerated sooner, if only a particular offender had been required to submit a DNA sample based on a previous conviction. Such cases are unrelated to underlying crime trends, and so produce idiosyncratic variation in the timing of database expansions. I exploit this variation to construct a set of simulated instrumental variables that predict the stock and flow of qualifying offenders, based

on the timing of expansions and pre-period crime rates. The resulting instruments are highly correlated with actual database size, but are not simultaneously determined or affected by how well states implement their database laws. They are correlated with crime rates only through 


\section{Introduction}

their correlation with database size.

Using these simulated instruments and data I collected on database size in each state, I find that larger databases are associated with lower crime rates during the years 2000 to 2008 . The estimated magnitudes imply that expanding databases to include individuals arrested (but not convicted) for serious felonies - a common policy proposal - would result in a $3.2 \%$ decrease in murders, a $6.6 \%$ decrease in rapes, a $2.9 \%$ decrease in aggravated assaults, and a $5.4 \%$ decrease in vehicle thefts. The absence of any significant impact on robbery or burglary rates suggests more limited use of DNA evidence from property crime scenes, or a high replacement rate for those crimes. That is, as profiled offenders are deterred or incapacitated, new, unprofiled offenders quickly take their place.

Furthermore, the size of the database has a significant, and perhaps unexpected, effect on the probability of arresting a suspect in newly-committed crimes. The probability of identifying a suspect should increase with DNA profiling for any given offender, but the decision to commit a new crime is endogenous and profiled offenders commit fewer crimes. A police officer's decision to arrest a suspect is also endogenous, and depends on the perceived strength of available evidence. I find that the probability of arresting a suspect in new cases falls significantly as database size increases, for all types of offenses except rape. This result is consistent with two hypotheses: (1) As DNA databases grow, "easy to catch" offenders are deterred or incarcerated quickly, so new crimes are committed by more elusive offenders. This would imply that-though fewer in number-new crimes are more difficult to solve. (2) As they become more familiar with DNA and other forensic evidence, police officers grow more aware of the limited accuracy of traditional methods, and are increasingly selective in whom they arrest. This would imply that arrests are fewer but more accurate.

Though DNA databases are widely used and rapidly growing, this paper is the first attempt to measure the impact of this law enforcement tool on crime. This analysis is a particularly useful contribution because DNA profiling is different from previously-studied crime prevention strategies in important ways.

Economists have long been intrigued by the ways in which changing the expected cost of committing a criminal offense affects an individual's decision to do so. Increasing the length of punishment appears to have some deterrent effect, but criminal offenders seem to heavily discount the future and so adding time to one's sentence many years out may have little impact on his behavior today. There is much less evidence regarding the other component of offenders' expected cost function: the probability of punishment. Increasing this parameter could be more cost effective than extending sentences because it is not as affected by high discount rates. Hiring additional police officers appears to lower crime, but police officers have many duties aside from 


\section{The Economics of Crime}

simply identifying and arresting offenders, so the precise treatment is unclear. DNA databases work mainly by increasing the probability of punishment, and so provide a unique opportunity to study the effects of this parameter on criminal behavior.

Furthermore, unlike prisons and police officers, DNA databases exhibit tremendous returns to scale. Given the rapidly decreasing marginal cost of a DNA profile (currently less than \$40), databases must only decrease crime a small amount to justify the financial cost of database expansions. (Privacy concerns are a separate issue and clearly more difficult to quantify.) Based on others' estimates of the effects of sentence enhancements and police hiring on crime rates, I calculate that the marginal cost of preventing a serious offense ${ }^{1}$ is about $\$ 7,600$ using longer sentences and \$26,300-62,500 using police officers. In contrast, my results on the impact of DNA databases suggest that the marginal cost of preventing a serious offense using DNA profiling is only $\$ 70$, and falling.

The paper proceeds as follows: Section 2 reviews related literature on the economics of crime; section 3 provides background on DNA database policy; section 4 discusses the data, empirical strategy, and results for the partial equilibrium analysis; section 5 does the same for the general equilibrium analysis; section 6 considers the cost effectiveness of DNA databases; and section 7 concludes.

\section{The Economics of Crime}

Economists have long been fascinated by criminal behavior, with an eye toward finding more cost-effective ways to reduce crime. Becker's (1968) classic model of criminal decision-making predicts that fewer people will choose to commit crime when the expected punishment increases. More explicitly, an individual will only offend if:

$$
\mathrm{E}(\text { Benefit })>\mathrm{E}(\text { Cost }) \text { and } \mathrm{I}(\text { Incarcerated })=0 \text {, }
$$

where $\mathrm{E}($ Cost $)=\mathrm{f}(p, \delta, s) ; p$ is the probability of conviction, conditional on reoffending; $\delta$ is a discount factor; and $s$ is the punishment (e.g., sentence length). $\mathrm{E}(\mathrm{Cost})$ is increasing in each of these parameters. I(Incarcerated) indicates whether the individual is currently incarcerated.

Consider a recently-released criminal offender who is deciding whether to recidivate. We can decrease the probability that he reoffends by increasing $p$ or $s$; this is the deterrent effect. If he reoffends and is convicted of the crime, which happens with probability $p$, he will be unable

\footnotetext{
${ }^{1}$ I will use the term "serious offense" to refer to FBI Index I offenses: felony homicide and non-negligent manslaughter, forcible rape, aggravated assault, robbery, burglary, larceny, and vehicle theft. These are the offenses tracked in the FBI's Uniform Crime Reports.
} 


\section{The Economics of Crime}

to reoffend again because he is in prison; this is the incapacitation effect. The total effect of a policy on crime could depend on either or both of these effects: Criminals can be deterred from offending when they are free, and physically prevented from offending when they are in jail.

It has been difficult to determine to what extent criminal behavior can be deterred in practice. Policies that depend primarily on the incapacitation effect are extremely costly: Housing inmates is expensive ${ }^{2}$ and US prisons are chronically overcrowded, so incarcerating new inmates might necessitate freeing others. ${ }^{3}$ Knowing whether E(Cost) can have a deterrent effect - i.e., whether potential offenders can be induced to police themselves - is therefore quite policy-relevant. Also of interest is the relative effectiveness of increasing $p$ and $s$. If offenders have high discount rates ( $\delta$ is small), increasing $s$ might have little to no deterrent effect, in which case increasing $p$ could be a more cost-effective way to lower crime rates.

Given the high cost of incarceration, measuring its effectiveness has been of primary interest. Many papers address the impact of incarceration on crime rates, typically finding at least some negative combined effect of deterrence and incapacitation. ${ }^{4}$ There is a related literature on the impact of "three-strikes laws" mandating extremely long sentences for an offender's third conviction; the consensus seems to be that this type of policy is not particularly cost-effective. ${ }^{5}$ Others attempt to isolate the deterrent effect of incarceration, with mixed results. For example, Abrams (2011) and Drago, Galbiati, and Vertova (2009) find that increasing expected sentences deters criminal behavior, while Lee and McCrary (2005) argue that 18-year-olds demonstrate extreme impatience or myopia when faced with the prospect of longer sentences when they legally become adults. A key takeaway from these studies is that if the future is heavily discounted, adding years to a sentence has minimal impact on an offender's cost-benefit calculation. It is also important to note that deterrent effects could be heterogeneous across age groups and other offender characteristics, so studies that find different effects are not necessarily in conflict.

Furthermore, longer or harsher punishments could have negative effects on criminal behavior that counteract any incapacitative and deterrent effects. There is both theoretical and empirical evidence that the experience of prison enhances offenders' criminal tendencies for a variety

\footnotetext{
${ }^{2}$ A study by the Pew Center on the States estimated the average cost of housing a prison inmate in the United States was $\$ 23,876$ per year in 2005 . This estimate varied by state, ranging from $\$ 13,000$ in Louisiana to $\$ 45,000$ in Rhode Island. (Pew Center on the States, 2008) In a separate analysis, the California state government estimated its total per-inmate annual costs to be $\$ 47,102$ during the 2008-09 fiscal year. ["California's Annual Costs to Incarcerate an Inmate in Prison." Available at http://www.lao.ca.gov/.] A large, and rapidly rising, incarceration expense is health care for the aging inmate population.

${ }^{3}$ A 2011 Supreme Court decision ordered California to reduce its prison population to $110,000-137.5 \%$ of capacity - because the overcrowded conditions constituted cruel and unusual punishment under the US Constitution. (Liptak, 2011) While this is an extreme example, the decision made the opportunity costs of incarceration explicit. ${ }^{4}$ See Levitt (1996), Johnson and Raphael (2011), Kuziemko and Levitt (2004), and Owens (2009).

${ }^{5}$ See Helland and Tabarrok (2007), Shepherd (2002), Stolzenberg and D'Alessio (1997), and Chen (2008).
} 


\section{The Economics of Crime}

of reasons (Pritikin, 2008; Camp and Gaes, 2005; Bayer, Hjalmarsson, and Pozen, 2009). In recent years, law enforcement has made greater use of increasingly-inexpensive computing power to impose harsher penalties without relying strictly on incarceration. (DNA databases are made possible by the same technological trends.) Unfortunately these policies can also have unintended consequences: Laws that require convicted sex offenders to register their whereabouts in a publicly-accessible database were intended to deter criminal behavior. They do increase the probability of catching repeat offenders, but also dramatically increase the stigma associated with the crime and make it very difficult for registered sex offenders to reintegrate into society. Prescott and Rockoff (2011) find that sex offender registries decrease the number of reported sex offenses by deterring nonregistered offenders, but that such laws actually increase recidivism among those who are registered. Lee (2011) investigates the effects of making a broader set of criminal records public, and finds similar effects: Some crime rates fall, but recidivism appears to increase. ${ }^{6}$

If offenders heavily discount the future, and/or if punishment has a strong negative influence on behavior, then increasing the probability of conviction might be a more cost-effective crime prevention strategy than increasing sentences. One way to increase $p$ is to increase the size of the police force, and several papers find that the effect of a larger police force on crime is negative. ${ }^{7}$ However, police officers have many responsibilities in addition to identifying and arresting criminal suspects, so the precise treatment implied by a larger police force is unclear. Furthermore, the effects of adding additional police officers are probably very local, and thus very expensive to achieve. Di Tella and Schargrodsky (2004) find that adding police officers on particular blocks after a terrorist attack in Argentina had a significant deterrent effect on motor vehicle thefts in those precise areas, but this suggests very limited returns to scale. Similarly, recent studies of foot patrols in crime hotspots imply that additional police officers are an effective intervention, but must be locally targeted. (See Ratcliffe et al., 2011, for a review.)

DNA databases work mainly by increasing $p$ for reoffenders, and the treatment is much cleaner than in the police officer case. Furthermore, this law enforcement tool exhibits tremendous returns to scale: Initial investments in crime labs and computer databases were costly, but the marginal cost of each offender profile is very low. Together, these facts suggest that DNA databases could be much more cost effective than other common crime-prevention methods.

So far there has been very little research on DNA databases. Roman, et al. (2008) conducted a

\footnotetext{
${ }^{6}$ While DNA databases to these other databases are similar in some aspects, they differ in one fundamental way: The records aren't public, so inclusion in a DNA database does not create a social stigma that might increase criminal behavior.

${ }^{7}$ For a review, see Levitt (2004). See also Levitt (1997) and subsequent comment, McCrary (2002), and reply, Levitt (2002). See also Corman and Mocan (2000), Klick and Tabarrok (2004), Evans and Owens (2007).
} 


\section{DNA Databases}

field experiment in five communities to test the cost-effectiveness of collecting DNA evidence in high-volume property crimes like burglary. The authors found that investigators identified more suspects and had more cases accepted for prosecution when they used DNA evidence, and that the suspects identified were more likely to have prior felony arrests and convictions. Bhati (2010) proposed and tested a structural model of recidivism using data on criminal histories and DNA profiling from Florida, and found 2-3\% reductions in recidivism risk attributable to deterrence for robbery and burglary, but increases in recidivism risk attributable to deterrence for other categories. The model's primary identification assumption is that the deterrent and probative effects of DNA profiling are separable, but in fact any deterrent effect is crucially dependent on an expected probative effect (that is, the increased probability of getting caught). In addition, it is likely that the deterrent effect begins at the time of DNA sample collection, which is quite salient, not on the (unknown, to the offender) date that the profile is ultimately uploaded to the database.

This paper uses criminal history data from a wider sample of states, new data on expansion timing and DNA database size, and identification strategies that avoid these potential problems, to investigate both the partial and general equilibrium effects of this highly-regarded law enforcement tool. Most notably, it is the first study to estimate the effects of DNA databases on crime rates.

\section{DNA Databases}

The United Kingdom led the way in using DNA as a law enforcement tool. The first national DNA database was established there in 1985, and two years later police used DNA evidence to solve two rape-murders in Narborough, England. Across the Atlantic, prosecutors in Orlando, Florida, read about the Narborough case and three months later used DNA testing to convict Tommy Lee Andrews of rape. In 1988, Colorado began collecting some convicted sex offenders' DNA; Virginia followed suit in 1989, collecting blood samples from sex and violent offenders, then expanded its law to include all convicted felons in 1990. By 1999, with the urging and financial support of the US Department of Justice, every state had established an offender DNA database. The state databases are currently linked by the FBI to form a national database called CODIS.

Each state has its own list of qualifying offenses, and these lists have expanded over time. Most started with sex offenses, added violent offenses, then burglary, then all felonies. Legislation that expanded the databases sometimes applied only to new convicts, but usually included anyone currently incarcerated for a qualifying offense. The goal of these databases was not to be tougher on criminals, per se, but to increase accuracy and hold the right people accountable for 


\section{DNA Databases}

their crimes. They appealed to legislators and voters as much for their potential to exonerate wrongly-convicted offenders (and prevent new mistakes) as they did for their ability to lock up career criminals. ${ }^{8}$ For this reason, liberal states were as likely as conservative states to quickly add new qualifying offenses.

States tended to expand their databases to include new qualifying offenses in response to widely-publicized "if only" cases: Cases in which terrible crimes could have been prevented, or a wrongful conviction and incarceration avoided, if only the database had included a particular type of criminal offender sooner. For example, Maine established a database including sex and violent offenders in 1996, after it was discovered that a brutal rape and attempted murder was committed by a man who would have been caught years earlier after committing a similar crime, if the database had been in place then. Georgia added all convicted felons to its database in 2000, after the indictment of a serial rapist. His lengthy criminal record would have made him traceable after the first attack, if only the database had been expanded earlier. Louisiana added all convicted felons to its database after a serial murderer with a history of simple burglary was identified; law enforcement claimed that several homicides could have been prevented if only he had been in the database. Similarly, California voters approved Proposition 69 in 2004, expanding the state database to include incarcerated felons, after it was revealed that a man who was recently convicted of raping fourteen women had served time for felony burglary years earlier. Voters were convinced that most of those rapes - and the terrorizing of a neighborhood for several years - could have been prevented if only the database had been expanded sooner. ${ }^{9}$

The timing of these "if only" cases produced idiosyncratic variation in the timing of state database expansions, with the result that expansion timing was not driven by underlying crime trends or state characteristics that might independently affect such trends. (To verify this, I regress expansion timing on pre-period crime rates, and find no significant relationship; these results are in Table 1.)

\footnotetext{
${ }^{8}$ Showing that DNA evidence does not match a convicted offender is often not enough to exonerate him in practice. In an interview with the Council for Responsible Genetics, Peter Neufeld, co-founder of the Innocence Project, described how DNA databases help exonerate wrongly-convicted individuals: "There are occasions where we get a DNA test result on a material piece of evidence from a crime scene which would exclude our client, but prosecutors still resist motions to vacate the conviction. In some of those cases, what then tipped the balance in our favor was that the profile of the unknown individual [whose DNA was found at the crime scene] was run through a convicted offender database and a hit was secured. Once we were able to identify the source of the semen or blood... we were then able to secure the vacation of the conviction for our client." He went on to add, "There's no question that there would be fewer wrongful convictions if there was a universal DNA databank." (CRG Staff, 2011) In 2007, Barry Scheck, the other co-founder of the Innocence Project, told the New York Times that "many of the people his organization had helped exonerate would have been freed much sooner, or would not have been convicted at all" if state databases included profiles from all convicted offenders. (McGeehan, 2007)

${ }^{9}$ More details on these and similar cases are in the Appendix.
} 


\section{DNA Databases}

Once laws were effective, states varied in their ability to promptly collect and analyze DNA samples from qualifying offenders. Collection was relatively quick and inexpensive so tended to begin on time, but the rate at which these samples were converted into searchable profiles (that is, analyzed in a laboratory and uploaded to the database) varied by state. The result was often large backlogs of samples waiting for analysis. This imperfect implementation is important for two reasons: First, any delays or mistakes in collecting DNA samples will result in a fuzzy regression discontinuity in the partial equilibrium analysis. (I will be unable to account for this, so it will bias my results toward zero.) Second, database size is likely a function of states' adeptness and motivation in analyzing DNA profiles, and these characteristics might impact crime through other channels. I use an instrumental variable strategy in the general equilibrium analysis to correct for any omitted variable bias.

Collection of a blood or saliva sample is quite salient to offenders, and it appears that most were well aware of the purpose of DNA collection. ${ }^{10}$ It was clear at the time of collection that their DNA would soon be in the state database and that the probability of getting caught for any future (or even past) crimes committed was suddenly higher than before. ${ }^{11}$ Thus, the deterrent effect of DNA profiling should begin upon collection. ${ }^{12}$ However, a DNA profile can only help law enforcement identify a suspect once it has been analyzed and added to the database. Thus, the probative effect begins only at the upload date. If the probative effect was delayed for some offenders, this will bias my results downward.

There was substantial variation in the timing of database expansions, with similar states often adding a particular offense years apart. (Full lists of database expansion dates are in Tables 2-4.)

For example, the case of felony rape: Colorado began collecting DNA samples from new rape convicts on May 29, 1988, but did not add incarcerated rapists until 2000. The nearby state of Wyoming did not establish a database until 1997, though it added both newly-convicted and incarcerated rapists at that point. Virginia began collecting DNA from newly-convicted and incarcerated rapists on July 1, 1989, but Maryland waited until 1994 to establish a database (including newly-convicted rapists only), while West Virginia added convicted and incarcerated rapists in 1995. In 1990, Florida began collecting DNA from newly-convicted and incarcerated rapists. The bordering state of Alabama did the same in 1994, while Georgia added newly-convicted rapists

\footnotetext{
${ }^{10}$ There is anecdotal evidence that law enforcement emphasized the purpose of DNA databases at the time of collection. Many offenders tried to avoid providing samples, suggesting they knew the probative power of DNA profiling. (Resulting legal challenges were defeated in every state.)

${ }^{11}$ It is extremely unlikely that offenders were aware of the size of sample backlogs; even policymakers were unaware of this problem for years. If they were aware of the delays in analyzing DNA samples, this would decrease the deterrent effect and bias my results toward zero.

${ }^{12}$ It is possible that this deterrent effect changes over time as offenders learn from personal or peers' experience how well DNA databases work.
} 


\section{DNA Databases}

in 1992 but did not include those incarcerated for the crime until 2000. Washington was one of the first states to collect DNA convicted rapists (it established its database in 1990), but did not expand its database to include those incarcerated for the crime until 2008. Nearby Oregon added both groups in 1991; Idaho waited until 1996.

The varied timing of expansions to include the non-violent felony offense of burglary is similarly unsystematic. Virginia was the first to add burglary, including both new convicts and inmates, beginning on July 1, 1990. Alabama went next, on May 6, 1994. However, the nearby state of Florida waited until 2000, and Mississippi did not follow suit until 2003. New York added new burglary convicts on December 1, 1999, but did not add incarcerated burglars until 2006. In contrast, nearby New Jersey added both convicted and incarcerated burglars in 2003. Oregon added newly-convicted burglars on October 23, 1999, but it took Washington until 2002 to do the same, and until June 12, 2008, to add incarcerated burglars to its list. In contrast, California added both groups in 2004. South Dakota added newly-convicted burglars in 2000, but North Dakota waited until 2009 to do the same. Nebraska began collecting DNA from newly-convicted and incarcerated burglars in 2006, while Wyoming had been doing so since 1997. In New England, Maine added newly-convicted burglars in 1996, but New Hampshire waited until 2003 to follow suit.

The expansion of databases to include all felonies was in some ways more controversial, because it included so many non-violent and white collar offenses. However, there remains substantial variation in the timing of all-felony expansions, with similar states often making this move years apart. New Mexico added convicted and incarcerated felons in 1998, while Arizona waited until 2004. Wyoming did so in 1997, but Colorado waited until 2002, and Idaho is not scheduled to add all felons until 2013. Alabama added these offenders in 1994, but Mississippi waited until 2003. Maine added all convicted felons to its database in 2001, and Massachusetts did so in 2004, but New Hampshire did not take this step until 2010. In 1990, Virginia became the first state to add all felons to its database, but Maryland did not do so until 2002, and West Virginia still has not added all felony convicts.

While this paper only examines the impact of profiling convicted offenders, it is important to note that the expansion of DNA databases is an ongoing policy issue. States continue to add new groups of potential offenders, particularly arrestees for various crimes. Some states have also begun conducting "familial searches" of existing profiles, with the hope that a partial DNA match will identify a close relative of the offender if he isn't in the database himself. This effectively expands the number of "profiled" offenders beyond those who are actually in the database.

As anecdotal successes accumulate, DNA profiling has won widespread praise from law 


\section{Partial Equilibrium Effects on Recidivism}

enforcement officials and political leaders as a valuable crime-prevention tool. ${ }^{13}$ However, the only outcome that is consistently tracked is "investigations aided" - the number of computer matches made between an offender profile and crime scene evidence, or linking two crime scenes. This is not a good measure of the value added by the technology, as it does not tell us how many of those matches would not have been made using traditional methods alone. Given the resources that state and federal government agencies continue to invest in DNA profiling, as well as the privacy concerns of civil libertarians, it is important to have an accurate estimate of the program's cost-effectiveness relative to other law enforcement tools.

\section{Partial Equilibrium Effects on Recidivism}

\subsection{Data}

In the partial equilibrium analysis, I test the effect of DNA profiling on aggravated assault convicts' subsequent criminal behavior. (The identification strategy is described below.) To do this, I need information on each state's database expansions and detailed criminal histories for all relevant offenders.

Information on the timing and details of state DNA database expansions comes directly from state legislative histories: I researched the relevant bills passed in each state, coding which crimes were added and which types of offenders were included (adults and/or juveniles, newly convicted offenders and/or current inmates, etc.) at each date.

Criminal history data were collected from the Departments of Correction (DOCs) in seven states: Florida, Georgia, Missouri, Montana, New York, North Carolina, and Pennsylvania. These are longitudinal, individual-level data that include each offender's dates of incarceration (including conviction and release dates), offense type(s), birthdate or current age, sex, and race. Female offenders, as well as anyone released before age 18 or after age 50, are excluded from my analysis. $^{14}$

\footnotetext{
${ }^{13}$ On March 4, 2002, Attorney General John Ashcroft told reporters that "DNA technology has proven itself to be the truth machine of law enforcement, ensuring justice by identifying the guilty and exonerating the innocent.... Experience has taught law enforcement that the more offenders that are included in the database, the more crimes will be solved."(DOJ News Conference transcript, available at http://www.justice.gov/archive/ag/speeches/2002/030402newsconferncednainitiative.htm)

${ }^{14}$ The vast majority of felons are men; $6.8 \%$ of offenders in my sample are women. Criminal offenses might be expunged if the offender is under age 18, so I restrict my attention to offenders who are adults during the entire post-release period. Recidivism risk decreases rapidly as offenders age, so the oldest releasees will not have a large impact on crime rates. More importantly, the effects of various demographic and other characteristics appears to be heterogeneous with age, so including these offenders does not help me precisely estimate more relevant (younger) releasees' behavior. My results are not sensitive to the arbitrary cutoff at age 50.
} 


\section{Partial Equilibrium Effects on Recidivism}

I use the details of each offender's criminal history to determine upon which release date (if ever) his DNA should have been collected, based on state DNA database laws. This required matching offenses as coded in DOC datasets to those listed in state statutes. In addition to the offenses committed, I take into account whether juveniles were excluded from DNA collection, and whether incarcerated inmates were included in addition to newly convicted offenders. To ease comparison across states, I also determine which offenses count as FBI Index I crimes (felony murder, forcible rape, aggravated assault, robbery, burglary, larceny, and vehicle theft), which have standard definitions.

Summary statistics are shown in Table 5.

\subsection{Empirical Strategy}

A direct comparison of the behavior of DNA-profiled and -unprofiled offenders is potentially problematic because, on average, these two groups have very different criminal histories, and it would be difficult to convincingly isolate the treatment effect from the effect of criminal predispositions. (If all violent criminals are in the DNA database while all non-violent criminals are not, we would not be surprised if DNA profiling were positively correlated with future violent behavior. However, we would be uncomfortable saying that DNA profiling caused that behavior.) To cleanly identify the effect of DNA profiling on individual behavior, we need exogenous variation in who must provide a DNA sample.

Conveniently, DNA database expansions created a series of natural experiments that provide just such variation. If two very similar offenders were released from prison just one day apart - one on the effective date of the expansion and the other the day before - one would be added to the database while the other would not. The effective date of each expansion thus introduced a sharp discontinuity in the probability of treatment for newly-qualifying offenders, but - crucially - not in any other characteristics that might affect recidivism risk. For offenders

released within a sufficiently small window around this threshold, any subsequent differences between the two groups can be attributed to the effect of DNA profiling.

A crucial assumption is that offenders' releases were not intentionally timed to occur before or after the database expansions. There is no evidence that this occurred, and the histogram of release dates in Figure 1 shows no unusual heaping around the expansion date.

The treatment effect is estimated by the coefficient $b$ in the following Regression Discontinuity specification:

$$
\operatorname{Pr}(\text { Reoffend and Convicted within } 3 \text { years })_{j}=a+b * \text { PostExpansion }_{j}+c * \mathrm{X}_{j} \text {, }
$$




\section{Partial Equilibrium Effects on Recidivism}

where $\mathrm{X}_{j}$ is a vector of demographic and criminal history information, a quadratic time trend, and state fixed effects; and $j$ indexes offenders. Standard errors are clustered by person. This OLS regression is run separately for three reoffense outcomes: commission of any offense, commission of a serious violent offense, and commission of a serious property offense.

The deterrent effect of DNA profiling depends on both the perceived size of the probative effect of DNA, and how close individuals are to the $\mathrm{E}$ (Cost) $=\mathrm{E}$ (Benefit) threshold. These could depend on both the age and criminal experience of an offender. I test for heterogeneous effects for two types of offenders: Those who were under age 25 at release, and those finishing sentences for their first incarceration.

There are three points to keep in mind when interpreting $b$ :

First, as described in the previous section, I do not observe actual DNA collection, but impute this based on individuals' criminal histories and incarceration spells. The coefficient $b$ therefore measures the effect of the intention to treat. This might not be the same as the treatment effect if states were slow to implement the new laws and/or if some offenders were mistakenly released before providing a DNA sample. ${ }^{15}$ To the extent that this occurred, $b$ will be biased toward zero.

Second, measuring recidivism accurately is difficult because offenses are only observed if the offender gets caught. That is, instead of the ideal outcome variable, $\operatorname{Pr}$ (Reoffend), I observe $\operatorname{Pr}($ Reoffend and Convicted), where

$$
\operatorname{Pr}(\text { Reoffend and Convicted })=\operatorname{Pr}(\text { Reoffend }) * \operatorname{Pr}(\text { Convicted } \mid \text { Reoffend })
$$

DNA profiling is expected to affect both factors on the right-hand side in equation 3 , in opposite directions. If DNA profiling helps law enforcement identify a crime's perpetrator, as designed, it increases $\operatorname{Pr}($ Convicted | Reoffend); this is the probative effect. This increases $\mathrm{E}$ (Cost) in equation 1 and should therefore reduce $\operatorname{Pr}$ (Reoffend); this is the deterrent effect. The coefficient $b$ estimates the net effect of DNA profiling. My data and identification strategy will not allow me to separate these two effects. Because the probative and deterrent effects cancel each other out to some extent, a significant positive estimate should be interpreted as a lower bound on the true probative effect, and a significant negative effect should be interpreted as a lower bound on the true deterrent effect. (Note that a zero net effect could mean that DNA

\footnotetext{
${ }^{15}$ Statistics on the frequency of such mistakes are unavailable for the states in my sample during the time period of interest, and it is difficult to estimate how large an effect this might have on my results. Even in more recent years, despite much more experience, states have a difficult time implementing their policies perfectly: New York State requires DNA collection upon intake to the Corrections system, and estimated a $92 \%$ collection rate within 2 months of an eligible sentence to a jail or prison in 2009. [http://criminaljustice.state.ny.us/pio/annualreport/2009crimestat-report.pdf, page 20]
} 


\section{Partial Equilibrium Effects on Recidivism}

databases have no effect on offenders, or that the deterrent and probative effects cancel each other out completely.)

Examples of how to interpret this net effect are in the Appendix. A net probative effect implies that many offenders continue to reoffend but are caught more easily, so DNA databases increase the incarceration rate among profiled offenders and we should expect the incapacitation effect on crime to be particularly important. A net deterrent effect implies that enough profiled offenders change their behavior that DNA databases decrease the incarceration rate among profiled offenders and we should expect the deterrent effect on crime to be particularly important. In both cases, the net effect tells us something about how the databases are working, though we would need more information to determine the precise magnitudes of each underlying effect. ${ }^{16}$

The third point regarding $b$ has to do with generalizability. This identification strategy depends on testing the effects of DNA databases immediately after they were expanded. It is quite possible, even likely, that the effectiveness of this law enforcement tool grows over time as police learn how to use it and offenders learn (perhaps via personal experience) of its probative effect. It is also possible that offenders gradually learn how to avoid detection by DNA analysis. Therefore, it is not clear whether the short-term effects found in this part of the paper should be thought of as upper or lower bounds on the longer-term effects. For this reason, the general equilibrium effects of DNA profiling on crime over the longer term will be an important supplement to this analysis.

\subsection{Results}

Graphs of the relationship between observed recidivism and release date are shown in Figures 26 , controlling only for state fixed effects. There appears to be a discontinuity in the outcome at the date of database expansion in several cases, particularly for young offenders.

Table 7 presents OLS (linear probability) results for the effect of DNA profiling on aggravated assault convicts. ${ }^{17}$ Coefficients show the percentage point change in the probability of observed recidivism.

Recall that the probative and deterrent effects go in opposite directions, so each will at least slightly counteract the other in determining whether an individual returns to prison. A positive coefficient should be interpreted as the lower bound on the probative effect, and a negative

\footnotetext{
${ }^{16}$ The lag between collection and analysis of DNA samples provides an opportunity to separate the deterrent and probative effects: only the deterrent effect is operative until the DNA profile is actually in the database. Exploiting this fact using data on the dates that DNA profiles were uploaded to the database is the focus of ongoing work.

${ }^{17}$ Using a linear probability model allows me to estimate marginal effects while minimizing assumptions about the functional form. Probit results are qualitatively similar and available upon request.
} 


\section{Partial Equilibrium Effects on Recidivism}

coefficient as the lower bound on the deterrent effect.

Results are shown separately by type of reoffense. The first three columns show results for the probability of a new conviction for any offense within three years, the second three columns for a serious violent offense (murder, forcible rape, aggravated assault), and the last three columns for a serious property offense (burglary, larceny, vehicle theft). The treatment variable is whether an individual's DNA was collected (i.e., whether he was released post-expansion).

On average, DNA collection has a net probative effect: The probability of reoffending and being convicted for any offense is 3.7 percentage points $(23.4 \%)$ higher for those with a profile in the DNA database than those without. This effect is statistically significant at the $\mathrm{p}<0.10$ level.

As columns (2) and (3) show, the effect of DNA profiling varies with offenders' age and criminal history. If the current incarceration was an offender's first, the net effect of DNA profiling was significantly lower, while if the offender was under age 25 at release, the net effect was significantly larger. The result is that DNA profiling has the largest net probative effect on young offenders with multiple convictions: they are 30.2 percentage points (85.6\%) more likely to be convicted of a crime within three years of release than their unprofiled counterparts. The effect is a bit smaller for young offenders with only one conviction (10.4 percentage points, or 35.6\%), and smaller again for older offenders with multiple convictions (6.7 percentage points, or 27.2\%). DNA profiling has no net effect on older offenders with only one conviction.

It is unclear whether these heterogeneous effects stem from differences in the deterrent effect or the probative effect (or both). It is possible that first-time offenders are more likely to commit types of crimes where DNA evidence is less available or infrequently analyzed (e.g. property crimes), so that the (net) probative effect is smaller for this group than for career offenders. Similarly, it is possible that young offenders commit types of crimes where DNA evidence is more available and frequently analyzed (e.g. violent crimes), so that the (net) probative effect is larger for this group.

To see if offenders' sorting into different types of offenses is driving the results, I consider the probability of a subsequent conviction for serious violent and property crimes separately, in columns (4)-(9). The same pattern emerges, though statistical power is limited due to the relatively rarity of these offenses. The effect of DNA profiling on young offenders is significantly more positive than for older offenders, even when attention is restricted to serious violent crimes. Similarly, the effect of DNA profiling on first-time offenders is significantly smaller than for career offenders, even when restricting attention to the commission of serious property crimes. These results suggest that differences in the probative effect of DNA profiling are probably not driving the heterogeneous effects.

Another possible explanation for the heterogeneity by criminal history is that the number 
of times someone has been convicted is a function of how easy he is to catch. DNA profiling might have a smaller probative effect on (apparent) first-time offenders because those offenders are more elusive, less sloppy when they commit crimes, and better able to avoid detection by DNA analysis. In other words, "first incarceration" might be proxying for "difficult to catch" while "career criminal" might be proxying for "easy to catch". However, while observed criminal history is endogenous, age is not. The large differences in the net probative effect of DNA profiling between older and younger offenders, even within specific types of crimes, is less likely to stem from differences in the probative effect alone. While far from conclusive, this suggests that deterrence is playing a role.

The effects presented in Table 7 are consistent for other bandwidths around the effective date of the laws, and for different time trend polynomials. Tables 11- 13 in the Appendix provide these results.

\subsection{Robustness Check: Placebo Test}

If differences between offenders released before and after the effective date are driven by underlying trends, and not the discontinuity in treatment at the effective date, I would see similar effects using a "placebo date" - an incorrect treatment threshold. Table 14 shows results using a placebo date of 500 days before the true effective date of state database expansions. Results are not significant, supporting the claim that DNA profiling is indeed causing the observed differences between profiled and unprofiled offenders.

\section{General Equilibrium Effects}

\subsection{Data}

For the general equilibrium analysis, I test the effect of DNA database size on crime rates and probability of arrest, using the simulated stock and flow of qualifying offenses-based on the timing of database expansions and pre-period crime rates-as instruments. (This identification strategy is described below.)

Data on state DNA database size over time did not previously exist, and so I have constructed a dataset using a variety of sources. I used state statistics whenever possible, and filled remaining holes with statistics reported by the media and estimates based on the number of profiles uploaded to CODIS. The resulting data on database size are likely measured with error, but instrumenting for them will remove any attenuation bias. 


\section{General Equilibrium Effects}

The instrumental variables required information on the timing and details of each state's DNA database expansions, as well as data on the number of reported offenses, by type, and the number of prison inmates, by type, in each state in 1999.

Information on database expansion timing comes directly from state legislative histories: I studied the relevant bills passed in each state, and coded which crimes were added and which types of offenders were included at each date. I denote each expansion as including convicted sex offenders, violent offenders, burglars, or all felons; and distinguish between expansions that included only new convicts from those that included incarcerated offenders.

Data on reported offenses come from the FBI's Uniform Crime Reports (UCR), and are available for murder, forcible rape, aggravated assault, robbery, burglary, larceny, and vehicle theft. Data on prison inmate populations by state come from the Bureau of Justice Statistics (BJS). I estimated the share in prison for each type of offense based on national data, also from the BJS. Data on the share of sentenced prisoners include the following offenses: murder, manslaughter, rape, other sex offenses, robbery, assault, other violent offenses, burglary, larceny, vehicle theft, fraud, other property offenses, drug offenses, other offenses. Population statistics used to calculate the number of offender profiles per 10,000 residents come from the United States census population estimates for each year.

This combination of sources yields 252 state-by-year observations where both database size and simulated instruments are available.

Crime rates are calculated using UCR data. I use the number of reported offenses in each category, divided by the total population of reporting jurisdictions in each state, and multiplied by 10,000 . (This is the number of crimes per 10,000 residents.)

Data for the probability of making an arrest in new crimes comes from the FBI's National Incident-Based Reporting System (NIBRS), which the agency is phasing in to replace the UCR. The NIBRS provides much richer data on each reported crime in a jurisdiction - including, most crucially, whether an arrest was made in each case — but is not available for all states in all years.

Summary statistics are shown in Table 15.

\subsection{Empirical Strategy}

The impact on profiled offenders is not the only determinant of DNA databases' effects on crime. Factors such as the reactions of unprofiled and never-offenders, the use of forensic evidence by law enforcement, the response to such evidence from jurors and judges ${ }^{18}$, and changes in the

\footnotetext{
${ }^{18}$ In particular, there is anecdotal evidence that jurors have come to expect high-quality forensic evidence in all types of cases. This is commonly referred to as the "CSI effect"; see Owens (2010) for a review of the available evidence on the existence of this effect.
} 


\section{General Equilibrium Effects}

behavior of crime victims and the general public all contribute to the general equilibrium effects of this new law enforcement tool.

I want to measure the effect of DNA databases on crime rates. DNA databases are designed to affect crime by increasing the probability that a known offender gets caught if he reoffends. Thus, the effectiveness of a state's DNA database increases with the probability that a potential offender is in the database; this probability is the intensity of treatment. In the years just after each database expansion, this probability is highly correlated with the size of the database relative to the state population. This is because most profiles are from offenders who are still active. However, as those profiled offenders get older, die, or move out of state, their profiles are not deleted, so databases continue to grow. The number of profiles per capita in the database therefore becomes a less useful proxy over time for the probability than an active offender will get caught. This paper examines the effect of DNA databases during the years 2000-2008, which is relatively early in their development, so database size should be highly correlated with the intensity of treatment.

The problem with this treatment variable is that database size is endogenous. The number of criminal offenders and offender DNA profiles in a state are simultaneously determined and positively correlated, so OLS estimates of the effect of database size on crime rates will be biased upwards. At the same time, states' adeptness and motivation with regard to implementing database laws will also affect database size. Because these state characteristics might affect crime and arrest rates through other channels, OLS estimates could suffer from omitted variable bias. I thus need an instrument for database size.

Within-state variation in database size comes largely from legislation adding new types of offenders. As described above, "if only" cases produced idiosyncratic variation in the timing of these expansions, so they are not a function of states' characteristics. I construct a set of instrumental variables that quantify the effects of the law changes by "simulating" the number of offenders who should qualify for inclusion in the database in each year, based on legislated qualifying offenses and pre-period (1999) crime rates and prison populations. By estimating both the stock and flow of qualifying offenders, I produce instruments that are strongly correlated with the actual number of profiles (F-statistic $=23$ ), but uncorrelated with crime and arrest rates through any other channel: Using pre-period statistics eliminates the simultaneity problem, and using the number of qualifying offenders - rather than the number of uploaded profiles corrects the omitted variable bias. This IV approach drastically reduces any biases that affect the OLS estimates. My instrumental first stage is specified in equation 4, and results are shown in 


\section{General Equilibrium Effects}

Table 6 in the Appendix.

$$
\begin{aligned}
\text { ProfileRate }_{s, t}=a_{j} * \sum_{j} & \text { } \\
& +b_{j} * \sum_{j}\left[\text { 1999OInmateRate }_{s, j} * \mathrm{I}_{\left.\left(\text {InmatesIncluded }_{s, t, j}\right)\right]+c_{j} * \mathrm{X}_{s, t},} * \text { YearsIncluded }_{s, t, j}\right.
\end{aligned}
$$

where $s$ indexes states, $t$ indexes years, and $j$ indexes offenses; and $\mathrm{X}_{s, t}$ is a vector of state fixed effects and a linear time trend. In words, the estimated number of profiles per 10,000 residents is a function of what the flow of new qualifying offenders would have been if crime rates remained at 1999 levels, multiplied by the number of years the law was in effect, plus what the stock of qualifying inmates would have been if prison populations remained at 1999 levels. ${ }^{19}$ Within each state, these numbers are a function only of (exogenous) variation in law timing. Subject to the identifying assumption that legislation timing does not depend on pre-period crime trends, they are thus valid instruments for the actual number of profiles.

\subsubsection{Effects on Crime Rates}

I expect that a larger DNA database will decrease aggregate crime rates. This effect should be largest for crimes where DNA evidence from crime scenes is most frequently collected and analyzed (e.g., violent crimes). The effect could be diminished if the replacement rate for offenders is high - that is, if new (unprofiled) offenders quickly enter the crime "market" to replace those who are deterred or incarcerated. The replacement rate might vary with the type of offense; in particular, it is probably higher for economically-motivated crimes like burglary than for emotionally-motivated violent crimes like murder. The effect of DNA databases on crime rates could also decrease over time if offenders learn to avoid detection by DNA analysis.

To estimate the effect of DNA profiling on crime rates, I run a 2SLS instrumental variable regression of crime rates on database size, using data from the UCR and the first stage specified in equation 4 . The results will be far more accurate that those produced by OLS. The second stage is specified in equation 5 . Standard errors are clustered by state.

$$
\text { CrimeRate }_{s, t, j}=u_{j} * \text { ProfileRate }_{s, t}+v_{j} * \mathrm{X}_{s, t},
$$

\footnotetext{
${ }^{19}$ For instance, consider a state that adds convicted and incarcerated burglars to its database in 2002, and in 1999 had 50 burglaries per 10,000 residents and 200 incarcerated burglars per 10,000 residents. The simulated profile rate would be 0 in 2001, 50a + 200b in 2002 (50 offenses * 1 year and 200 inmates), 100a + 200b in 2003 (50 offenses * 2 years and 200 inmates); 150a + 200b in 2004 (50 offenses * 3 years and 200 inmates), and so on. However, the simulated instrument would predict no change in database size for a state that had no burglaries or incarcerated burglars in 1999. The intensity of treatment would, appropriately, be higher for the first state than the second.
} 


\section{General Equilibrium Effects}

where $s$ indexes states, $t$ indexes years, and $j$ indexes offenses; and $\mathrm{X}_{s, t}$ is a vector of state fixed effects and a linear time trend.

\subsubsection{Effects on Arrest Probability}

DNA profiling should increase the probability of arresting a suspect in a new crime, for any given offender. However, the decisions both to offend and to make an arrest are endogenous, and the general equilibrium effect of database size on the probability of arresting a suspect is ambiguous due to selection effects.

On the arrest side, widespread use of DNA evidence meant law enforcement officers began seeing examples of cases in which traditional methods (e.g., eyewitness testimony) led them to the wrong suspect. Indeed, one of the primary arguments for this technology was that it would increase the accuracy of arrests and convictions. Because of this, an increase in the size of DNA databases might result in police officers' becoming more selective when making arrests, and the probability of arresting a suspect in new offenses might fall. However, if DNA database matches provide great enough certainty in a large enough number of cases, the probability of making an arrest could rise.

On the offender side, if DNA profiling has no deterrent or incapacitation effects, the probability of arresting a suspect increases as the probability that an offender's DNA has been collected increases. With deterrent and/or incapacitation effects, $\operatorname{Pr}$ (Offend | DNA Collected) is less than $\operatorname{Pr}$ (Offend | DNA Not Collected). That is, profiled offenders are less likely than unprofiled offenders to commit new crimes. In an extreme case, $\operatorname{Pr}$ (Offend | DNA Collected) goes to zero, so all new crimes are committed by unprofiled offenders, and the probability of arresting a suspect in new crimes does not change as the database grows.

Now consider a scenario in which there are two types of offenders: skilled and unskilled. Unskilled offenders are always easier to catch than skilled offenders, but DNA profiling would likely have different effects on the two groups. In an extreme case, unskilled offenders in the database are convicted with near certainty, while skilled offenders adapt their behavior to avoid detection by DNA analysis and their probability of conviction is unchanged. In this scenario, $\operatorname{Pr}$ (Offend | Unskilled, DNA Collected) goes to zero, and all new crimes are committed by skilled (i.e., difficult to catch) offenders. The probability of arresting a suspect would then be lower than it was before DNA profiling began.

To estimate the effect of DNA profiling on the probability of arresting a suspect in new crimes, I run a 2SLS IV regression of the probability of arresting a suspect on database size, using data from the NIBRS and the same first stage as above (specified in equation 4 ). The second stage 


\section{General Equilibrium Effects}

(linear probability model) is specified in equation 6 . Standard errors are clustered by state.

$$
\operatorname{Pr}(\text { Arrest Suspect })_{j}=w_{j} * \text { ProfileRate }_{s, t}+z_{j} * \mathrm{X}_{i, t} \text {, }
$$

where $s$ indexes states, $t$ indexes years, $j$ indexes type of offense, and $i$ indexes reporting jurisdictions (e.g. county); and $\mathrm{X}_{i, t}$ is a vector of jurisdiction fixed effects and a linear time trend. Each observation is a unique reported crime incident.

\subsection{Results}

\subsubsection{Effects on Crime Rates}

The estimated effects of database size on crime rates are presented in Table 16, and are presented as standardized beta coefficients. This means that a one standard deviation (SD) increase in the size of the DNA database results in a 0.26 SD decrease in the murder rate, a 0.66 SD decrease in the rape rate, a $0.30 \mathrm{SD}$ decrease in the aggravated assault rate, and so on. (As expected, OLS estimates are biased upwards.) To ease interpretation of the magnitudes of these effects, I consider the implied impact of a common policy proposal: Back-of-the envelope estimates suggest that the addition of individuals arrested (but not convicted) for serious felony offenses would result in a $12 \%$ increase in the size of an average database, per year. ${ }^{20}$ Assuming a linear effect on crime, such an expansion would result in a $3.2 \%$ decrease in murders, a $6.6 \%$ decrease in rapes, a $2.9 \%$ decrease in aggravated assaults, and a 5.4\% decrease in vehicle thefts.

Robbery and burglary rates are not significantly changed, despite the significant effect of DNA profiling on property crimes seen in the previous section. This suggests the following: (i) criminals have learned how to avoid leaving DNA evidence at property crime scenes, (ii) they have realized law enforcement does not generally analyze the DNA evidence they do leave (i.e., that the probative effect is relatively small), and/or (iii) there may be a higher replacement rate for these types of offenses - new offenders entering the crime "market" when profiled offenders are incapacitated or deterred.

The large negative effect on vehicle theft rates is likely due to clearing "volume" crimes, where a small number of offenders commit a large number of crimes. Vehicle theft is a relatively highskill crime often connected to chop shops, and most of these crimes are committed by vehicle

\footnotetext{
${ }^{20}$ States reported 76.3 arrests per 10,000 residents for Index I violent and property offenses in 2008. (UCR 2008) Based on 2006 estimates, $61 \%$ of those charged with a serious felony have no prior felony conviction (so are probably not yet in the database), and approximately $46 \%$ are not ultimately convicted of a felony in that case (so would in most cases not need to submit DNA under current law). (State Court Processing Statistics, 2006) This suggests that adding Index I felony arrestees to state databases would increase profiles collected by 21.4 per 10,000 residents per year $(76.3 * 61 \% * 46 \%)$, which was $12 \%$ of the average database size in 2008 .
} 
theft "rings." (Emily, 2010) If DNA databases lead law enforcement to a few key individuals, they will prevent many future crimes.

\subsubsection{Effects on Arrest Probability}

The estimated effects of database size on the (linear) probability of arresting a suspect for new offenses. The results are presented in Table 17. I find that the probability of arrest falls as DNA databases grow, in almost all cases. A 50\% (approximately 1 SD) expansion of an average database would imply that the probability of arresting a suspect falls by $42.9 \%$ in murder cases, $9.9 \%$ in aggravated assaults, $12.6 \%$ in robberies, $7.7 \%$ in burglaries, $2.4 \%$ in larcenies, and $6.1 \%$ in vehicle thefts. Rape is the exception: the probability of arresting a suspect is not significantly different for this crime. This suggests that the probative effect of DNA evidence counterbalances any effects on the composition of offenders and police officers' behavior in rape cases.

Assuming a linear effect, expanding DNA databases to include individuals arrested for serious felony offenses (i.e., by $12 \%$ ) would decrease the probability of making an arrest in new cases by $10.3 \%$ for murder, $2.4 \%$ for aggravated assault, $3.0 \%$ for robbery, $1.9 \%$ for burglary, $0.6 \%$ for larceny, and $1.5 \%$ for vehicle theft.

These results are consistent with the following hypotheses: (i) police become more selective in arresting suspects, implying that arrests are fewer but more accurate; and/or (ii) "easy to catch" offenders are deterred or incapacitated most quickly, implying that new cases - though fewer in number - are more difficult to solve.

\subsection{Robustness Check: Alternative IV Specifications}

One might be concerned that variation in the states' pre-period crime and prison statistics could be correlated with future crime trends, due to regression to the mean. I test the effect of two alternative IV specifications on the general equilibrium results: (1) using simple indicator variables for whether a particular type of offender qualifies for inclusion in the state database in each year, and (2) using national (instead of state) crime and prison statistics to estimate the stock and flow of qualifying offenders. Table 18 shows first stage results for these alternate specifications, along with the results for my preferred specification (using state statistics to estimate the stock and flow of qualifying offenders).

Table 19 shows results using each of these three IVs. Results are qualitatively similar, though the effect of DNA databases on larceny rates is no longer significant in the alternative specifications. 
6 Cost Effectiveness of DNA Databases

\subsection{Robustness Check: Controlling for Other Law Enforcement Policies}

Even if "if only" cases were uncorrelated with underlying crime trends in each state, it is possible they prompted state legislatures to do more than just expand DNA databases. The estimated effects of DNA databases would suffer from omitted variable bias if these simultaneous policy changes themselves affected crime rates. The most likely (and potentially worrisome) policy change is an increase in police hiring. I use FBI data on the number of police officers in each state to proxy for this and similar law enforcement efforts. Controlling for police officers per capita has very little effect on the estimates; see Table 20 for these results.

\section{Cost Effectiveness of DNA Databases}

The value of CODIS (and the state DNA databases it links) depends on (1) whether the benefits of the program exceed its costs, and (2) its cost-effectiveness relative to that of other law enforcement tools such as hiring more police officers or lengthening prison sentences.

The cost of collecting and analyzing each DNA sample is currently less than $\$ 40$, according to a U.S. Department of Justice estimate, and less than $\$ 20$ in several states. ${ }^{21}$ The marginal cost of analyzing new DNA samples continues to fall as technology improves, and, unlike law enforcement tools such as prisons and police officers, DNA databases exhibit tremendous returns to scale: There were large initial fixed costs in terms of crime lab equipment and computer databases, but the cost of expanding the program is relatively small.

A back-of-the-envelope calculation based on the estimated social costs of crime in McCollister, et al. (2010), is shown in Table 21 and suggests that DNA databases have resulted in dramatic savings. Based on my estimates in section 6, each profile resulted in 0.57 fewer serious offenses, for a social cost savings of approximately $\$ 27,600$. In $2010,761,609$ offender profiles were uploaded to CODIS. At $\$ 40$ apiece, this cost the state and federal governments approximately $\$ 30.5$ million, but saved $\$ 21$ billion by preventing new crimes.

Owens (2009) estimates that a marginal year of incarceration results in 1.5 fewer serious offenses and costs $\$ 11,350$ in Maryland. This implies that preventing a marginal crime via longer sentences costs $\$ 7,600$. Estimates of the effect of police on crime rates range from 0.8 to 1.9 fewer serious offenses per officer, per year.(Levitt, 2002) Salary.com reports that the median salary for a police officer in the United States is about $\$ 50,000$. This implies that preventing a marginal crime by hiring more police costs between $\$ 26,300$ and $\$ 62,500$, not including benefits. Both of

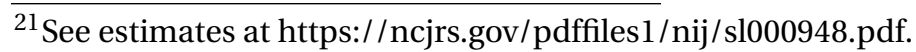




\section{Discussion}

these law enforcement tools are likely to become more expensive in the future, as health care costs rise.

In contrast, my estimates suggest that each additional DNA profile prevents 0.57 crimes, implying that the cost of preventing a marginal crime is $\$ 70$, and falling. Even using a very conservative estimate of the number of crimes prevented - the lower bound of the $95 \%$ confidence interval each DNA profile prevents 0.11 crimes, at an implied cost of \$364 per crime.

If DNA databases reduce crime in part by increasing incarceration rates, the cost of the additional incarcerations should be included in the total cost of using this technology. (In that case, the number above is most comparable to that of hiring police officers, which should also have both probative and incapacitation effects on crime. If incarcerations increase due to more police activity, those costs are not included here.) However, it is possible that DNA profiling simply changes the timing of prison sentences: For instance, instead of catching someone for a violent crime and putting him in prison for 30 years when he's 35, DNA databases might catch him for a more minor offense that puts him in prison for 5 years when he's 25 . Because of the sharp decrease in criminal behavior with age, moving the sentence up in this way could be a much more cost-effective use of incarceration dollars. Results from a preliminary analysis of DNA database size on state incarceration rates, using the same IV strategy as in Section 5.2, are presented in Table 22. While imprecise, they do not suggest that the number of inmates increases as DNA databases grow. (I am exploring these effects further in ongoing work.)

Based on this evidence, DNA databases appear much more cost effective than the most common alternatives.

\section{Discussion}

Though DNA databases have great potential - and, anecdotally, much success - there has been little rigorous analysis of their impact on criminal behavior or crime rates. I present evidence that DNA profiling has a large net probative effect, particularly for young offenders. This results in an incapacitation effect, as those offenders continue to commit new crimes but are caught more frequently (or at least more quickly) when they do. I also present evidence that DNA profiling has a much smaller net probative effect on first-time offenders, suggesting that increasing the

(expected) cost of criminal behavior might deter this group from reoffending. More research is needed to better understand the magnitudes of these effects.

DNA databases appears to have a particularly large effect on young offenders. To the extent that incarceration has a criminogenic effect - that is, that it increases one's propensity to commit crime - catching these offenders more quickly or more often when they commit new crimes 


\section{Discussion}

could produce a cohort of more hardened criminals. Because this happens when they are still relatively young, they will have little (non-criminal) human capital in the form of education, employment experience, or ties to friends and family to rely on when they are released. This could have large unintended consequences for the cohort that came of age during this period, and possibly for their families. This is a topic that is worth further study.

The combination of incapacitation and deterrent effects has a significant and negative impact on many crime rates, though there is some suggestion that this effect is mitigated for many property offenses. It is unclear to what extent this will change as DNA technology advances. If law enforcement is not using DNA evidence from property crime scenes to its full potential, the probative (and, in turn, deterrent) effects of DNA profiling could eventually increase for those offenders. If there is a high replacement rate for these economically-motivated crimes, DNA databases might have little effect unless they eventually contain profiles of individuals before they offend.

The other component of DNA databases is crime scene evidence. This is often more complicated and costly to analyze, and many governments are focusing on expanding the number of qualifying offenders rather than clearing backlogs of unanalyzed evidence. While this paper shows a significant effect of collecting serious felons' DNA profiles, it is unlikely that this effect will be linear as governments add more minor offenders (or non-offenders) to the database. While the marginal cost of adding more (potential) offenders' profiles is small, at some point it will be more cost-effective to channel legislative energy and funding into analyzing evidence and finding matches with the profiles that already exist. This is particularly true if perceived privacy costs are large. 


\section{Appendix}

\subsection{Examples of "if only" cases that prompted database expansions}

Maryland, 1994: The brutal rape of a 64-year-old woman in Daly City, Virginia, (a suburb of Washington, D.C.) and the quick identification of her attacker using the Virginia DNA database led quickly to nearby Maryland's establishment of a DNA database for sex offenders.(Sanchez, 1993; Coia, 1994)

Maine, 1996: "If Maine had had a DNA database when 18-year-old Lisa Garland's body was discovered in an Alton gravel pit, her murder might have been solved immediately and a 15-yearold York girl might have escaped the horror of being raped, stabbed and left for dead by Garland's killer." (Ordway, 1996)

Georgia, 2000: State lawmakers moved a step closer to ... approval of a system to begin collecting DNA samples from Georgia's 42,000 prisoners. ... Such a database, [GBI Director Milton "Buddy" Nix Jr.] said, could have helped officials stop the suspect in the Athens serial rapes in 1996 after the first attack. A man indicted in January on four counts of rape already had a number of convictions that would have put him in the database, therefore making him traceable after the first attack. (Pruitt, 2000)

Illinois, 2002: 1993 Brown's Chicken murders were solved because of the state database. DNA from saliva on a chicken wing found at the scene was profiled and a match was found. One of the two men charged gave a videotaped confession when confronted with the evidence; this event prompted quick passage of expansion of the database to include all felons. (Patterson, 2002)

Louisiana, 2003: "If a proposed DNA database had been in place, the search to identify a suspect in the serial killings [of 5 women since Sept. 2001] could have ended before Monday.... Lee has a criminal record, including a conviction for simple burglary that landed him on probation. ... 'This is why it is so important to extend the database to arrestees.'" (Barrouquere, 2003)

California, 2004: "Mark Wayne Rathbun raped 14 women around Long Beach, Calif., from 1997 to 2002, including an elderly widow recovering from cancer surgery. In September, the 34-year-old drifter was sentenced to 1,030 years plus 10 life terms. But many of those rapes might have been prevented, law enforcement officials say, had California's new DNA law been in place years ago. 


\section{Appendix}

... Rathbun had served time for felony burglary years before." (Cannon, 2004)

\subsection{Interpreting the Net Effect of DNA Profiling}

Consider an example:

Suppose there are one hundred offenders in a DNA database, and that $\operatorname{Pr}$ (Reoffend $\mid$ No DNA profile $)=0.5$ and $\operatorname{Pr}($ Convicted $\mid$ Reoffend, No DNA profile) $=0.5$. (That is, without DNA profiling, fifty of the offenders would have reoffended, and twenty-five of those would have been caught.) Note that observed recidivism is lower than the true recidivism rate: $\operatorname{Pr}$ (Reoffend and Convicted | No DNA profile $)=0.25\left(.5^{*} .5\right)<0.5$.

Suppose that DNA profiling increases the probability of getting caught to 0.8 . If there is no deterrent effect - perhaps the offenders haven't learned how DNA works yet - the same number of people (fifty) reoffend, but the number who get caught increases from twenty-five to forty $(50 * 0.8)$. We conclude that DNA databases have a probative effect: $\operatorname{Pr}$ (Reoffend and Convicted $\mid$ DNA profile $)=0.4>\operatorname{Pr}($ Reoffend and Convicted $\mid$ No DNA profile $)=0.25-$ a $60 \%$ increase . Because there is no deterrent effect going in the opposite direction, this is the same as the true probative effect: $(0.8-0.5) /(0.5)=60 \%$.

Now consider the other extreme: DNA profiling has no probative effect — perhaps DNA evidence from crime scenes is not analyzed - but offenders think it does. The perceived probative effect increases $\mathrm{E}$ (Cost) so that it exceeds $\mathrm{E}$ (Benefit) for some offenders, and only forty of them reoffend. With no change in $\operatorname{Pr}$ (Convicted | Reoffend), twenty of those are caught (40*0.5), five fewer than without DNA profiling. We conclude that DNA databases have a deterrent effect: $\operatorname{Pr}($ Reoffend and Convicted $\mid$ DNA profile $)=0.2<\operatorname{Pr}($ Reoffend and Convicted $\mid$ No DNA profile $)=$ 0.25 - a $20 \%$ decrease. Because there is no probative effect going in the opposite direction, this is the same as the true deterrent effect: $(0.5-0.4) /(0.5)=20 \%$.

The true impact of DNA databases likely lies between these two extremes, where both deterrent and probative effects are operative, and $b$ will measure their net effect. If after DNA profiling $\operatorname{Pr}$ (Convicted $\mid$ Reoffend, DNA profile) is 0.8 , and $\operatorname{Pr}$ (Reoffend $\mid$ DNA profile $)=0.4$, forty people reoffend and $32(40 * 0.8)$ of them are caught. This is more than the twenty-five who would have been caught without DNA profiling, so the net effect of the treatment is positive and we say that DNA databases have a net probative effect: $\operatorname{Pr}$ (Convicted and Reoffend $\mid$ DNA profile $)=0.32>$ $\operatorname{Pr}$ (Convicted and Reoffend $\mid$ No DNA profile $)=0.25-$ a $28 \%$ increase in observed recidivism . Note that because the deterrent effect masks some of the improvement in conviction rates, this

estimate is a lower bound on the true probative effect: $(0.8-0.5) /(0.5)=$ a $60 \%$ increase in the probability of getting caught. 
Alternatively, imagine that some offenders are easily deterred by the higher probability of conviction - perhaps they discount the future less - so that $\operatorname{Pr}$ (Reoffend | DNA profile) falls to 0.2 . In this case, only twenty offenders reoffend, and sixteen $\left(20^{*} 0.8\right)$ of them are caught. This is less than the twenty-five who would have been caught without DNA profiling, so the net effect of the treatment is negative and we say that the DNA databases have a net deterrent effect: $\operatorname{Pr}$ (Reoffend and Convicted $\mid$ DNA profile $)=0.16<\operatorname{Pr}$ (Reoffend and Convicted $\mid$ No DNA profile) $=0.25-$ a $36 \%$ decrease in observed recidivism. Note that because the probative effect masks some of the effect on individuals' behavior, this estimate is a lower bound on the true deterrent effect: $(0.5-0.2) /(0.5)=$ a $60 \%$ decrease in the probability of reoffending. 


\section{References}

\section{References}

Abrams, D. S. (2011): "Estimating the Deterrent Effect of Incarceration using Sentencing Enhancements,” Institute for Law and Economics, Research Paper No. 11-13.

Agrell, S. (2004): "All suspects should be forced to give DNA: Fantino: Credited for rape arrest," National Post, August 9.

Aguillard, D. (1991): “DNA prints: Missouri to require blood from violent, sex criminals," St. Louis Post-Dispatch, June 22.

Ahumada, R. (2004): "Cold Cases Hot Stuff for Criminalists; State Labs Scour Evidence Samples by the Thousands for DNA Clues That Solve Crimes - Or Free the Innocent," Modesto Bee, September 13.

Babcock, P. (1990): “State Adding DNA Bank to Anti-Crime Tools,” Washington Post, July 12.

Baker, M. (2004): "Crime: Cold case murder heats up with arrest after 3 years; Unidentified man killed three years ago," Sun Herald, August 11.

Baldwin, D. (2004): “Tight budget delays DNA tests,” The Oklahoman, July 25.

Barnum, A. (1994): "DNA databases nail U.S. offenders; Genetic master list is being compiled by FBI from samples convicts have been forced to provide,” Toronto Star, April 10.

Barrouquere, B. (2003): “Legislation seeking more DNA samples,” The Advocate, May 27.

Bayer, P., R. Hjalmarsson, and D. Pozen (2009): "Building Criminal Capital behind Bars: Peer Effects in Juvenile Corrections,” Quarterly Journal of Economics, 124(1), 105-147.

Becker, G. S. (1968): “Crime and Punishment: An Economic Approach,” Journal of Political Economy, 76, 169-217.

Begley, S., G. Carroll, and K. Springen (1994): “Blood, Hair and Heredity,” Newsweek, July 11.

Begley, S., and A. Rogers (1994): “It's All in the Genes,” Newsweek, September 5.

Bhati, A. (2010): “Quantifying the Specific Deterrent Effects of DNA Databases,” Justice Policy Center, The Urban Institute.

Bischoff, L. A. (2004): "State Clearing DNA Backlog: It could lead to solving some older cases, officials say," Dayton Daily News, August 30.

Buelow, M. C. (1993): “State to bank on DNA tests to solve crimes,” Capital Times, August 23.

Bullers, F. (2004): “County hopes analysis of DNA eases backlog,” Kansas City Star, August 13.

Camp, S. D., and G. G. Gaes (2005): "Criminogenic Effects of the Prison Environment on Inmate Behavior: Some Experimental Evidence,” Crime and Delinquency, 51(3), 425-442. 


\section{References}

Canham, M. (2004): "DNA labs reheating cold cases; Best 'witness': The science gives police a sure way to connect a suspect to a crime scene; DNA is better evidence than eyewitness," Salt Lake Tribune, July 26.

Cannon, A. (2004): “Not quite like on 'CSI',” U.S. News \& World Report, December 20.

Chachere, V. (1994): “Audit: Police DNA program won't work without more funds,” Tampa Tribune, November 4.

Chen, E. Y. (2008): “Impacts of 'Three Strikes and You're Out' on Crime Trends in California and Throughout the United States," Journal of Contemporary Criminal Justice, 24(4), 345-370.

Clouse, T. (2004): "Investigation of murder suspect widens; Police study possible link to kidnap, rape in June," Spokesman Review, August 21.

Coia, D. A. (1994): “New member for DNA club; Maryland aims at sex offenders," Washington Times, March 25.

Corman, H., and H. N. Mocan (2000): "A Time-Series Analysis of Crime, Deterrence, and Drug Abuse in New York City,” The American Economic Review, 90, 584-604.

Craig, J. (2004): “Man charged in teenager's 1982 strangulation; DNA used in case against sex offender confined at McNeil Island," Spokesman Review, August 19.

CRG Staff (2011): “Forensic DNA, The Liberator: Interview with Peter Neufeld,” GeneWatch, 24(5).

Daisley, B. (1993): "Use of databases has sparked controversy over DNA typing," Lawyers Weekly, February 26.

Dalessio, D. J. (1990): “DNA test: The telltale heart of science,” San Diego Union-Tribune, December 18.

DeMonia, R. (1994): “Leader in FBI's DNA Program to Establish System in Alabama,” Birmingham News, July 13.

DiTella, R., and E. Schargrodsky (2004): "Do Police Reduce Crime? Estimates Using the Allocation of Police Forces After a Terrorist Attack,” The American Economic Review, 94(1), 115-133.

Drago, F., R. Galbiati, and P. Vertova (2009): “The Deterrent Effects of Prison: Evidence from a Natural Experiment," Journal of Political Economy, 117(2).

Eddy, S. (1990): "OC opens lab to nab criminals by their genes; DNA testing hailed as cost-cutting and error-free tool," Orange County Register, February 16.

- (1991): "County assists pilot DNA project; Data base set up for genetic matching," Orange County Register, February 22.

Editors (1991): “Invest in Sex-Offender Bank,” Sunday Oregonian, May 5. 


\section{References}

_ (1992): “New York Needs a DNA Crime Data Base,” New York Times, May 29.

_ (1994): “A Genetic Sherlock and O.J.," Plain Dealer, August 29.

_ (2004): “Catch Up on DNA Backlog,” Sunday Oregonian, August 1.

Egelko, B. (2004): "Court OKs DNA collection from parolees; Panel reverses itself on constitutionality of mandatory blood draws," San Francisco Chronicle, August 19.

Emily, J. (2010): “Dallas task force to test using DNA to solve auto thefts," Dallas Morning News, January 19.

Evans, W. N., and E. G. Owens (2007): “COPS and crime,” Journal of Public Economics, 91, 181-201.

Fischer, K. (2004): “Expanded DNA Use Urged by Officials; Initiative Would Require Felons to Contribute Genetic Material; Foes Cite Expense,” Contra Costa Times, July 23.

Fisher, M. (1995): “The Simpson Legacy: Transformed Attitudes Toward Justice System,” The Washington Post, October 6.

Ford, R. (1994): “DNA database for criminals,” The Times, August 19.

Garfinkel, S. L. (1991): “The Jury Is Out on DNA,” Christian Science Monitor, March 27.

Goldberg, C. (1998): “DNA Databanks Giving Police A Powerful Weapon, and Critics,” The New York Times, February 18.

Goldston, L. (1994): “Sex Offenders’ DNA Put on File,” San Jose Mercury News, June 5.

Gottlieb, J. (1994): "Lawmakers continue marathon talks progress on crime bills as health mandates approved," Times Union, July 3.

Heath, T. (1994): "2 More Schaefer Measure Gain Legislative Ground; Panel Backs Child Support, Sex Offender Bill," Washington Post, March 20.

Helland, E., and A. Tabarrok (2007): “Does Three-Strikes Deter: A Non-Parametric Investigation,” Journal of Human Resources, 42(2), 309-330.

Herendeen, S. (2004): “DNA Links Inmate to '86 Murder; 65-Year-Old Woman Raped, Killed Behind a Church in Turlock," Modesto Bee, August 26.

Hughes, D. (2000): "Police hope DNA adds more counts; bond set at \$2 million as murder charge nears," Arkansas Democrat-Gazette, April 13.

Hurrell, M. (1992): “Criminals could go on to world blacklist,” The Times, May 8.

Johnson, R., and S. Raphael (2011): "How Much Crime Reduction Does the Marginal Prisoner Buy?," Journal of Law and Economics, (forthcoming). 


\section{References}

Kalil, J., and B. Haynes (2004): "Arrest made in serial rape case," Las Vegas Review-Journal, September 1.

Kelley, T. (1993a): “Bill on sex criminals gets an OK,” Wisconsin State Journal, October 14.

_ (1993b): “DNA testing expanded in crime bill,” Wisconsin State Journal, September 24.

_ (1993c): “Panel Endorses DNA Plan,” Wisconsin State Journal, May 27.

Kirby, T. (1989): “Home Office plans register of criminals' DNA profiles,” The Independent, May 24.

Klick, J., and A. Tabarrok (2004): "Using terror alert levels to estimate the effect of police on crime," American Law and Economics Association Annual Meetings, Paper 38.

Krueger, A. (1989): "Genetic data as good as fingerprints; DNA technique helps separate guilty, innocent,” San Diego Union-Tribune, July 12.

Kuziemko, I., and S. D. Levitt (2004): "An empirical analysis of imprisoning drug offenders," Journal of Public Economics, 88, 2043-2066.

Lambe, J., and G. E. Rice (2004): "Sanders easily wins bid to remain prosecutor," Kansas City Star, August 4.

Lantigua, J. (1994): “DNA File Solves '91 Rape Case Genetic Fingerprint Betrays Man Who Tried To Wash Away Evidence,” Miami Herald, June 22.

LaPlante, M. D. (2004): “DNA database may solve 'cold' S.L. rape cases,” Salt Lake Tribune, August 19.

Lavania, H. (2004): “Sweeps of DNA Faulted,” Wichita Eagle, September 11.

Lee, D. N. (2011): “The Digital Scarlet Letter: The Effect of Online Criminal Records on Crime and Recidivism," Unpublished working paper.

Lee, D. S., and J. McCrary (2005): “Crime, Punishment and Myopia," NBER Working Paper No. 11491.

Levitt, S. D. (1996): “The Effect of Prison Population Size on Crime Rates: Evidence from Prison Overcrowding Litigation," Quarterly Journal of Economics, 111(2), 319-351.

- (1997): "Using Electoral Cycles in Police Hiring to Estimate the Effect of Police on Crime," American Economic Review, 87(3), 270-290.

(2002): "Using electoral cycles in police hiring to estimate the effects of police on crime: Reply,” American Economic Review, 92(4), 1244-1250.

(2004): "Understanding why crime fell in the 1990s: Four factors that explain the decline and six that do not," Journal of Economic Perspectives, 18(1), 163-190. 


\section{References}

Lindley, T. (1994): “Evans: Senate DNA Bill Steels State’s Crime Fight,” Birmingham News, April 29.

Liptak, A. (2011): "Justices, 5-4, Tell California to Cut Prisoner Population," New York Times, May 23.

Long, P., and L. Getter (1991): “Gainesville Murder Case Rides on Suspect's DNA Test,” Miami Herald, January 26.

Mangalonzo, J. (2011): “Robbery charges piling up against 29-year-old,” The Hawk Eye, January 29.

Marvell, T. B., and C. E. Moody (2001): “The Lethal Effects of Three-Strikes Laws,” Journal of Legal Studies, XXX, 89-106.

McCollister, K. E., M. T. French, and H. Fang (2010): “The cost of crime to society: New crimespecific estimates for policy and program evaluation,” Drug and Alcohol Dependence, 108, 98-109.

McCrary, J. (2002): "Using electoral cycles in police hiring to estimate the effect of police on crime: Comment," American Economic Review, 92(4), 1236-1243.

McGeehan, P. (2007): “New York Plan for DNA Data in Most Crimes,” New York Times, May 14.

Meier, B. (1994): “Simpson Team Taking Aim at DNA Laboratory,” New York Times, September 7.

Meisol, P. (1987): “DNA test gains stature in courtroom; Orlando rape conviction may encourage increased use of genetic 'fingerprinting', St. Petersburg Times, December 27.

Michaud, S. G. (1988): “DNA Detectives,” The New York Times, November 6.

Miller, J. (1994): "Few challenges to DNA testing in Illinois cases; but Simpson hearing another matter," State Journal-Register, July 5.

Missouri Department of Corrections (2011): "Sunshine Law Offender Data File," Online database.

Moss, B. (1994): “Governor wants to boost DNA files,” St. Petersburg Times, August 13.

Napper, R. (2009): "FBI to Buchanan: DNA backlog will be fixed," Bradenton Herald, October 23.

Nelson, M. (2011): "Making Sense of DNA Backlogs, 2010-Myths vs. Reality," National Institute of Justice, https://www.ncjrs.gov/pdffiles1/nij/232197.pdf.

Niles, L. (1994): “Patrol Moves to DNA Testing,” Omaha World Herald, November 7.

Ordway, R. (1996): “State DNA lab will speed up investigations,” Bangor Daily News, October 24.

Orr, R. (1989): “Funding may curtail growth of county crime lab,” The Miami Herald, March 13. 


\section{References}

Owens, E. G. (2009): "More Time, Less Crime? Estimating the Incapacitative Effect of Sentence Enhancements," Journal of Law and Economics, 52(3), 551-579.

(2010): “Media and the Criminal Justice System," Unpublished working paper.

Patterson, J. (2002): “Felon DNA database gets Senate OK,” Chicago Daily Herald, May 30.

Peters, J. W. (2010): “New Rule Allows Use of Partial DNA Matches,” New York Times, January 25.

Pew Center on the States (2008): "One in 100: Behind Bars in America 2008," http://www.pewcenteronthestates.org.

Prescott, J., and J. E. Rockoff (2011): “Do Sex Offender Registration and Notification Laws Affect Criminal Behavior?," Journal of Law and Economics, 54(1), 161-206.

Press, A. (1994): “'They're walking all over the Bill of Rights,' inmate says; State resumes sampling blood from inmates for DNA database," Virginian-Pilot, July 21.

Price, J. (1995): “Governor's plan proposes aid for forensic studies; Computer link would put state on genetic information highway," Charleston Daily Mail, January 23.

Pringle, D. (1994): "Seduced by the gene genie: The Government wants criminals to be genetically fingerprinted. But, warns David Pringle, a DNA database may put the innocent at risk," The Independent, March 28.

Pritikin, M. H. (2008): “Is Prison Increasing Crime?,” Wisconsin Law Review, pp. 1049-1108.

Pruitt, K. (2000): “House OKs prisoner DNA file,” Atlanta Journal and Constitution, March 10.

Raab, S. (1992): “Cuomo Seeks Genetic Data of Offenders,” New York Times, May 10.

Ramsey, A. (1990): “Magistrate rules out new DNA tests law,” The Advertiser, June 15.

Ratcliffe, J., T. Taniguchi, E. Groff, and J. Wood (2011): “The Philadelphia Foot Patrol Experiment: A randomized controlled trial of police patrol effectiveness in violent crime hotspots," Criminology, 49, 795-831.

Roman, J. K., S. Reid, J. Reid, A. Chalfin, W. Adams, and C. Knight (2008): “The DNA field experiment: Cost-effectiveness analysis of the use of DNA in the investigation of high-volume crimes," NCJ, 222318.

Sanchez, C. (1993): “Woman, 64, Describes Rape; Man Picked by DNA Database Has Hearing,” Washington Post, December 15.

Schnurr, C. (1992): "Ga. among 20 states using DNA to convict criminals; Data bank of sex offenders is planned," New York Times, November 21.

Schrage, M. (1994): “Today, It Takes a Scientist To Catch a Thief,” Washington Post, March 18. 


\section{References}

Schwaneberg, R. (2004): “10 years later, Megan's legacy,” The Star-Ledger, July 25.

Seppa, N., and P. Brinkman (1994): "Data Banks Put Genetics On File; Privacy Issues Under Review,” Wisconsin State Journal, September 18.

Shepherd, J. M. (2002): “Fear of the First Strike: The Full Deterrent Effect of California's Two- and Three-Strikes Legislation,” Journal of Legal Studies, 31(1), 159-201.

SoRelle, R. (1994): "Anniversary of a revolution; PCR technique to copy DNA still sheds light a decade later," Houston Chronicle, September 19.

Sorensen, J. R. (1994): “Accord reached on DNA bank; Other crime measures stall," Buffalo News, July 3.

Staff (1994a): “Howard toughens line on Justice Bill,” The Lawyer, October 18.

_ (1994b): “The State: Blood samples needed; Judge clears the way for prisoner-DNA plan," Wilmington Star-News, October 16.

_ (2004a): "Faster bio-database," R\&D Magazine, August.

— (2004b): "How DNA is Tested in Crime Labs," Seattle Post-Intelligencer, July 22.

(2004c): "Rhode Island Health Department's forensic laboratory to expand efforts of DNA sampling," Rhode Island Lawyers Weekly, July 26.

_ (2009): "Rep. Buchanan meets with FBI on DNA database," US Fed News, October 24.

Stencel, M. (1993): "DNA database leads police to suspect; Genetic material used for first time in Virginia to bring charge," Washington Post, October 19.

Stolzenberg, L., and S. J. D’Alessio (1997): “'Three Strikes and You're Out’: The Impact of California's New Mandatory Sentencing Law on Serious Crime Rates," Crime and Delinquency, 43(4), 457-469.

Stone, K. (1993): “L.A. Cops Want Use of DNA Technology to Become Routine,” Time-Picayune, July 20.

Strickler, L. (2009): “Thousands of Rape Kits Wait to be Tested,” CBS News, November 10.

Sullivan, J. F. (1994): “Whitman Approves Stringent Restrictions on Sex Criminals,” New York Times, November 1.

Tabarrok, A., and E. Helland (2009): "Measuring Criminal Spillovers: Evidence from Three Strikes," Review of Law and Economics, 5(1), 251-268.

Thomason, R. (2011): “DNA testing: a li'l swab might do you right," Huntsville Times, February 6. 


\section{References}

Toomey, S. (2004): "DNA ties Valley man to 3 rapes since 1999; Charged: State, national databases link Colby Griffeth to crimes," Anchorage Daily News, September 10.

Uyttebrouck, O. (1994): "DNA tests help link handyman to slayings in Levy, police say," Arkansas Democrat-Gazette, December 7.

Vendel, C. (2011): “Jackson makes court appearance on charges in Waldo area sex assaults," Kansas City Star, February 18.

Walsh, T. (2004): “Software for DNA Matching Took Technology Higher," Detroit Free Press, September 9 .

Wells, C. (2011): “DNA hit brings closure in rape case," Sarasota Herald Tribune, January 28.

Wilham, T. (2009): "Police: Notorious Rapist Caught; 'Ether Man' allegedly raped 12 women in Albuquerque and Texas," Albuquerque Journal, November 2.

Willing, R. (2000): "Many rapists were thieves first: Results may lead to taking DNA for lesser crimes,” USA Today, July 10.

— (2004): “'CSI effect' has juries wanting more evidence,” USA Today, August 5.

Witkin, G., and K. Hetter (1994): “High-tech crime solving," U.S. News \& World Report, July 11.

Yoon, C. K. (1991): “DNA prints point scientific finger at guilty party,” Oregonian, October 3.

Zoghby, J. (1994): “DNA Results May Not Be Ready For Hearing,” Birmingham News, June 22. 


\section{Tables and Figures}

9 Tables and Figures

Table 1: Effect of 1990 crime rates on timing of database expansions

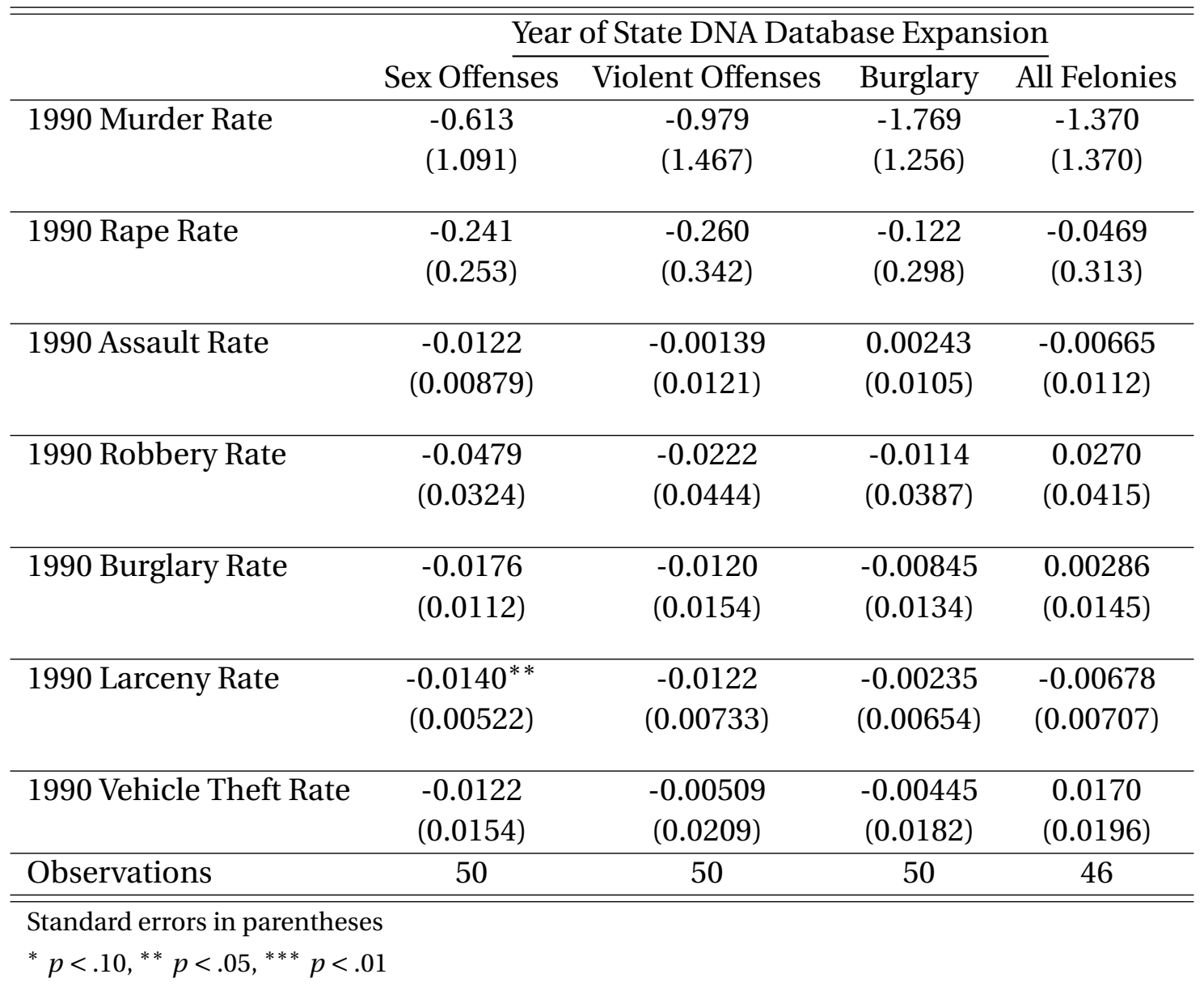


9 Tables and Figures

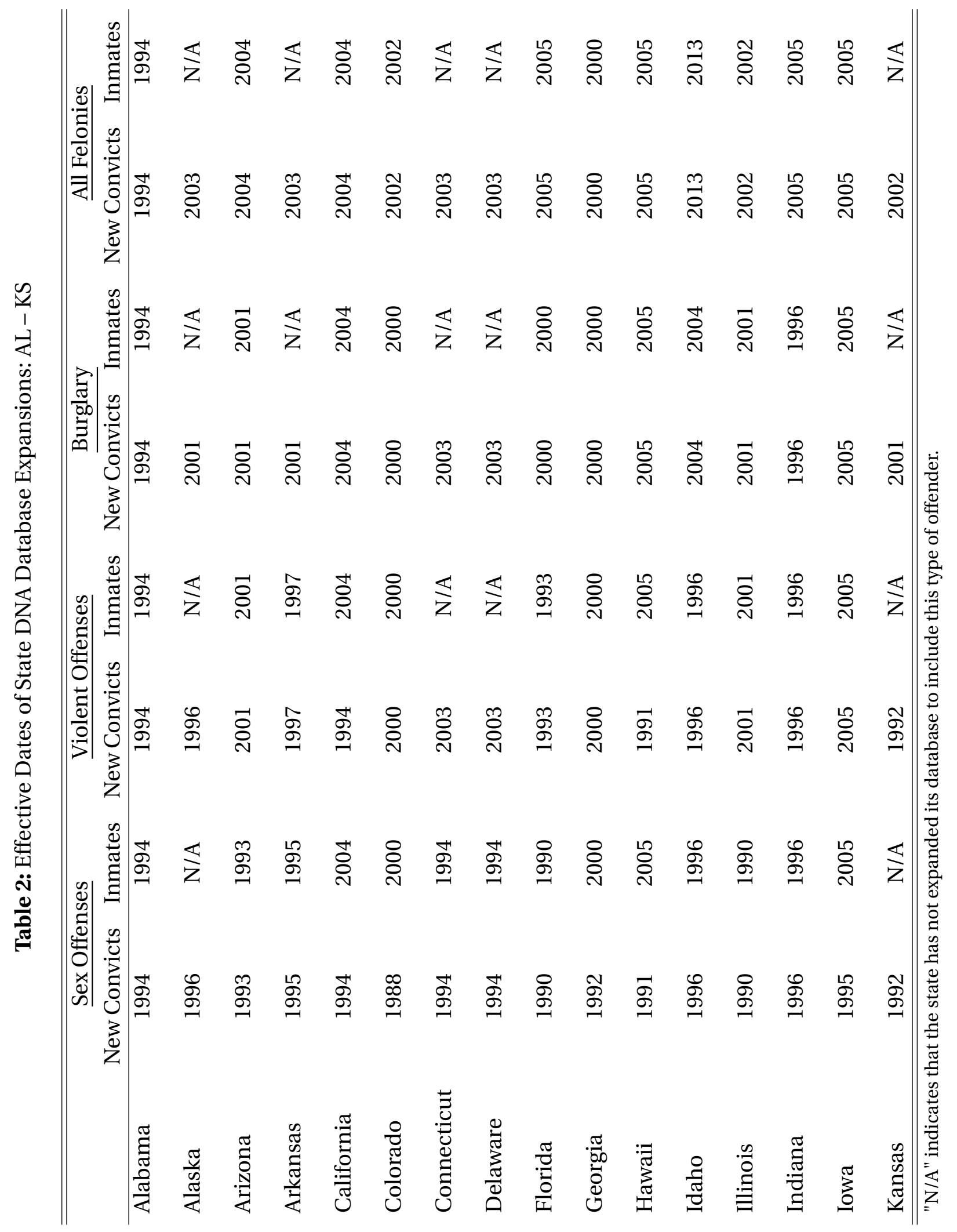


9 Tables and Figures

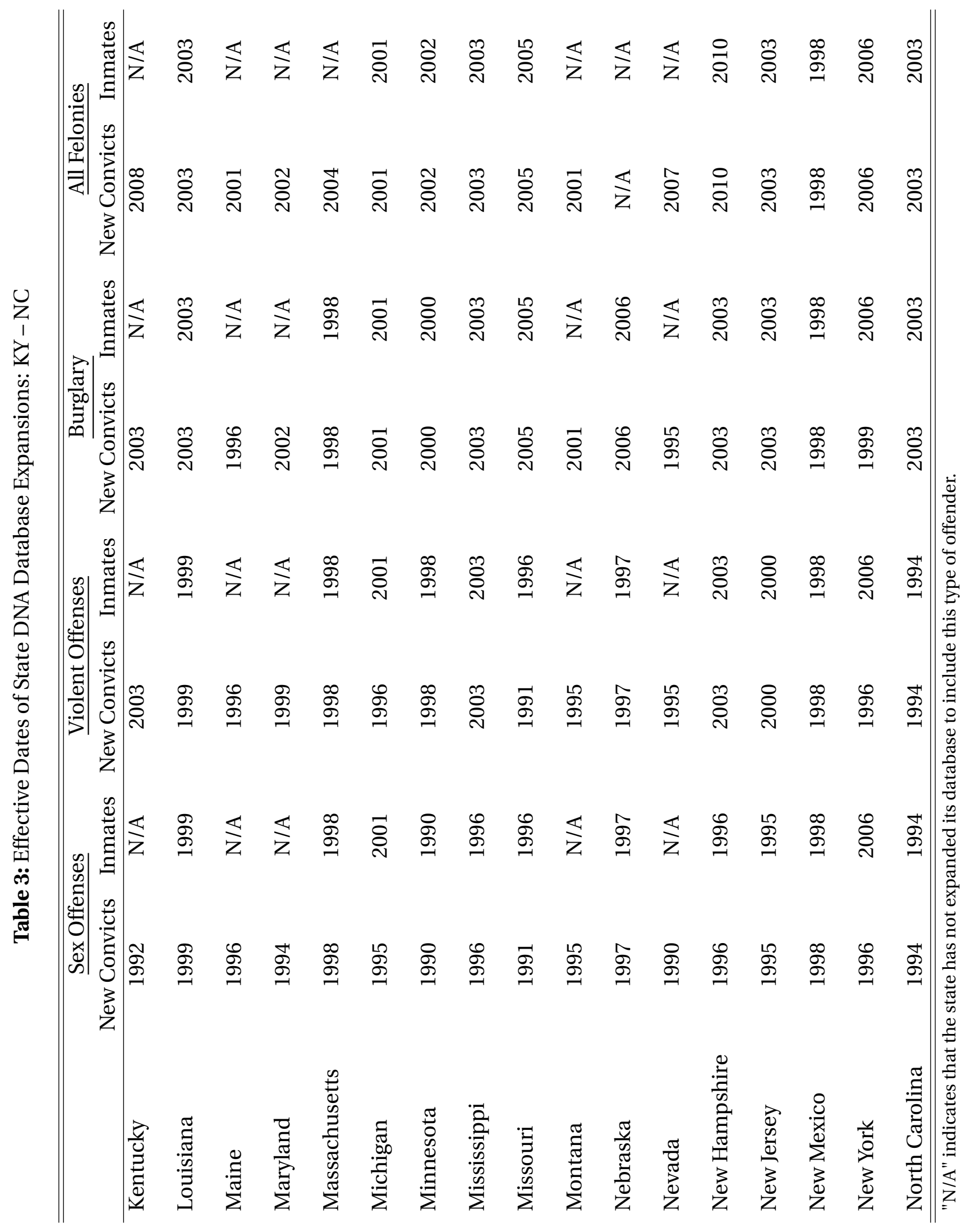




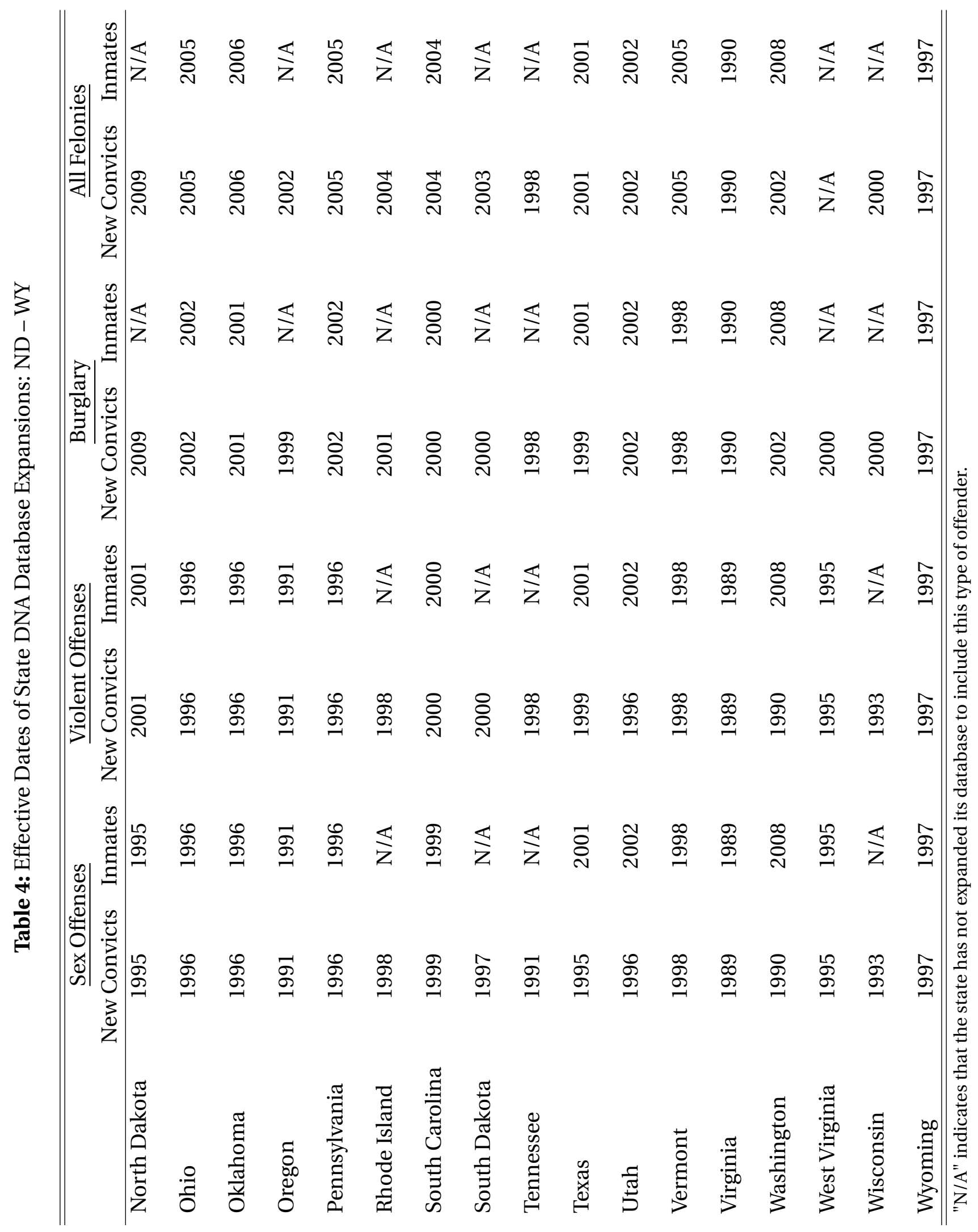




\section{Tables and Figures}

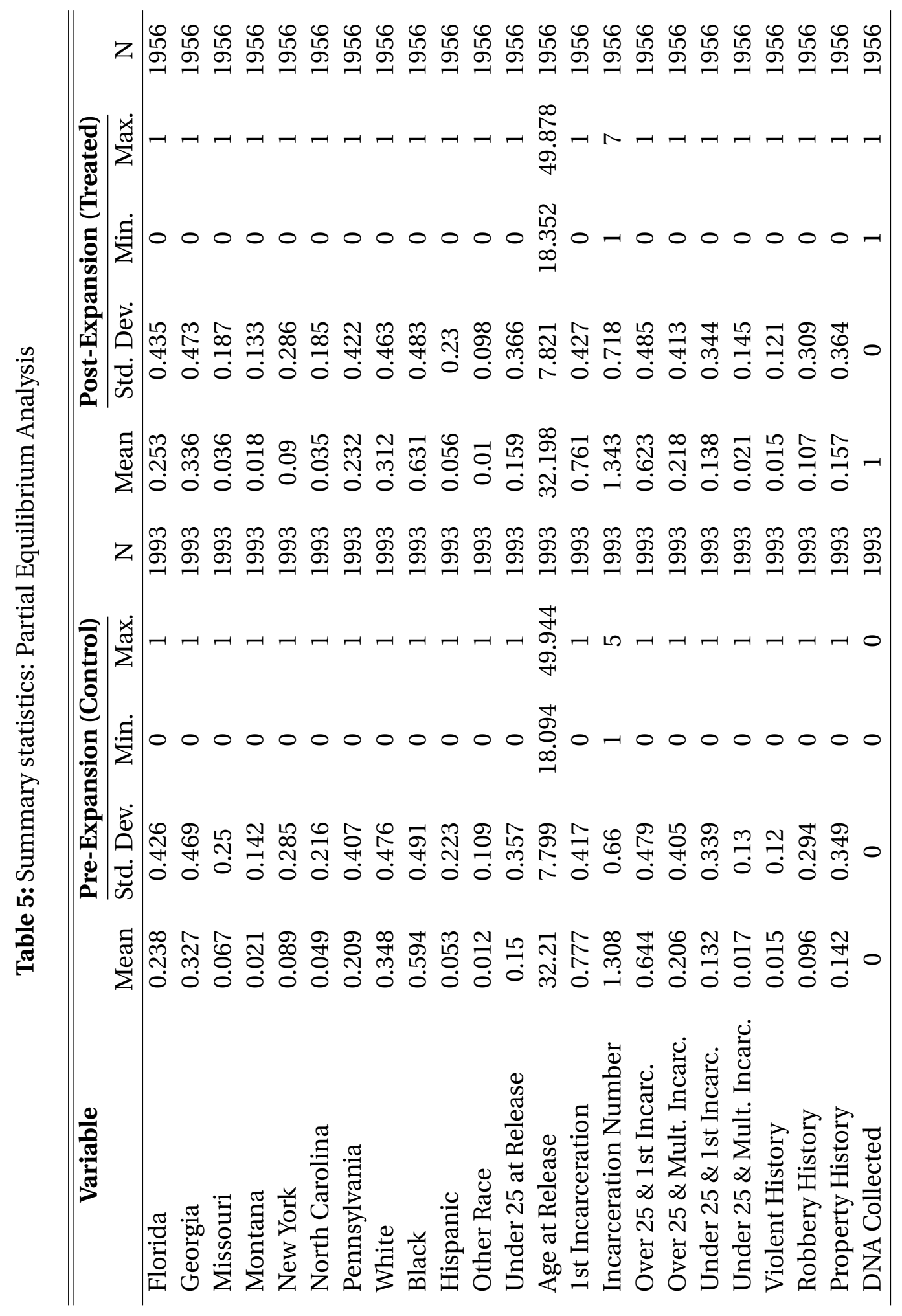




\section{Tables and Figures}

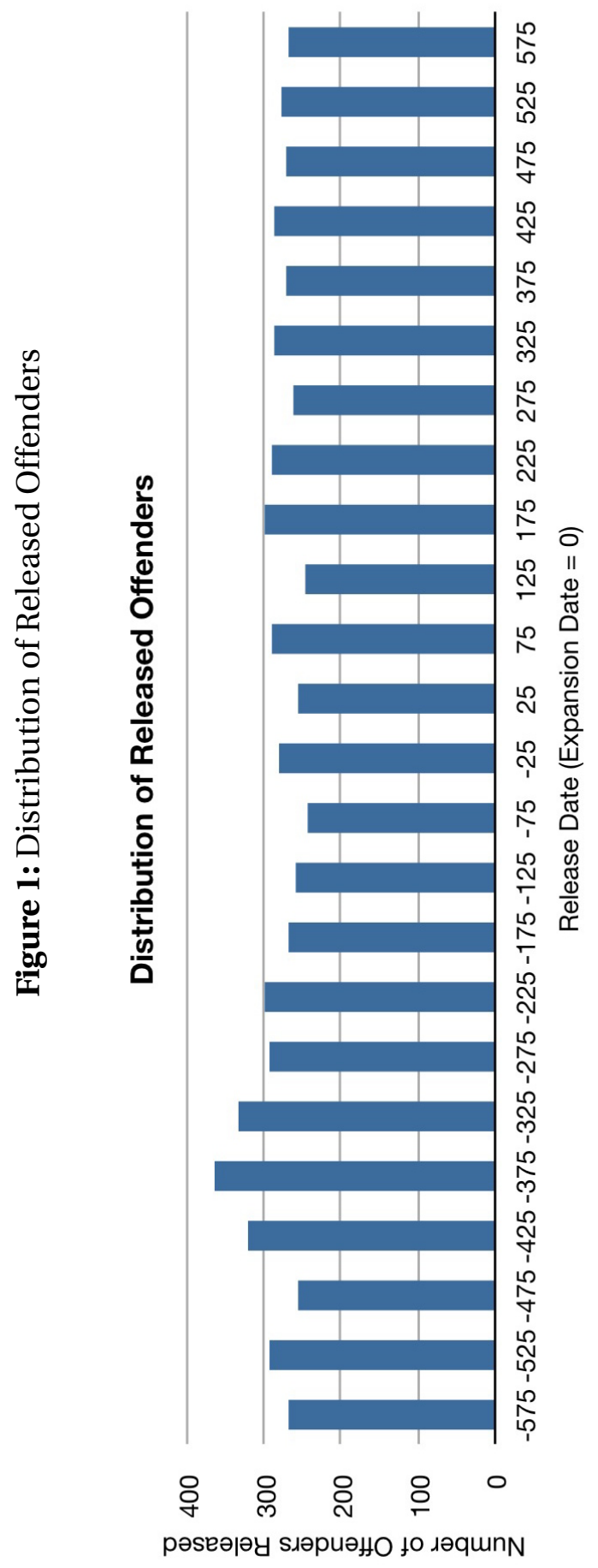




\section{Tables and Figures}

Table 6: First Stage: Effect of Instruments on Number of Profiles

\begin{tabular}{lc}
\hline \hline & Profiles \\
\hline Sex Offense Convicts & -1.370 \\
& $(2.124)$ \\
Violent Offense Convicts & 0.0467 \\
& $(0.0458)$ \\
Burglary Convicts & 0.0163 \\
& $(0.0803)$ \\
All Felony Convicts & $0.0427^{* * *}$ \\
& $(0.0150)$ \\
Sex Offense Inmates & 55.00 \\
& $(41.79)$ \\
Violent Offense Inmates & -14.82 \\
& $(11.41)$ \\
Burglary Inmates & -22.08 \\
& $(14.66)$ \\
All Felony Inmates & $8.131^{*}$ \\
& $(4.492)$ \\
\hline$N$ & 252 \\
F & 23.21 \\
\hline \hline
\end{tabular}

Standard errors in parentheses

Includes time trend and state fixed effects. SEs are clustered by state.

Convictions, incarcerations, and profiles are per 10,000 state residents.

${ }^{*} p<.10,{ }^{* *} p<.05,{ }^{* * *} p<.01$ 
Figure 2: $\operatorname{Pr}$ (Reoffend and Convicted of Any Offense)

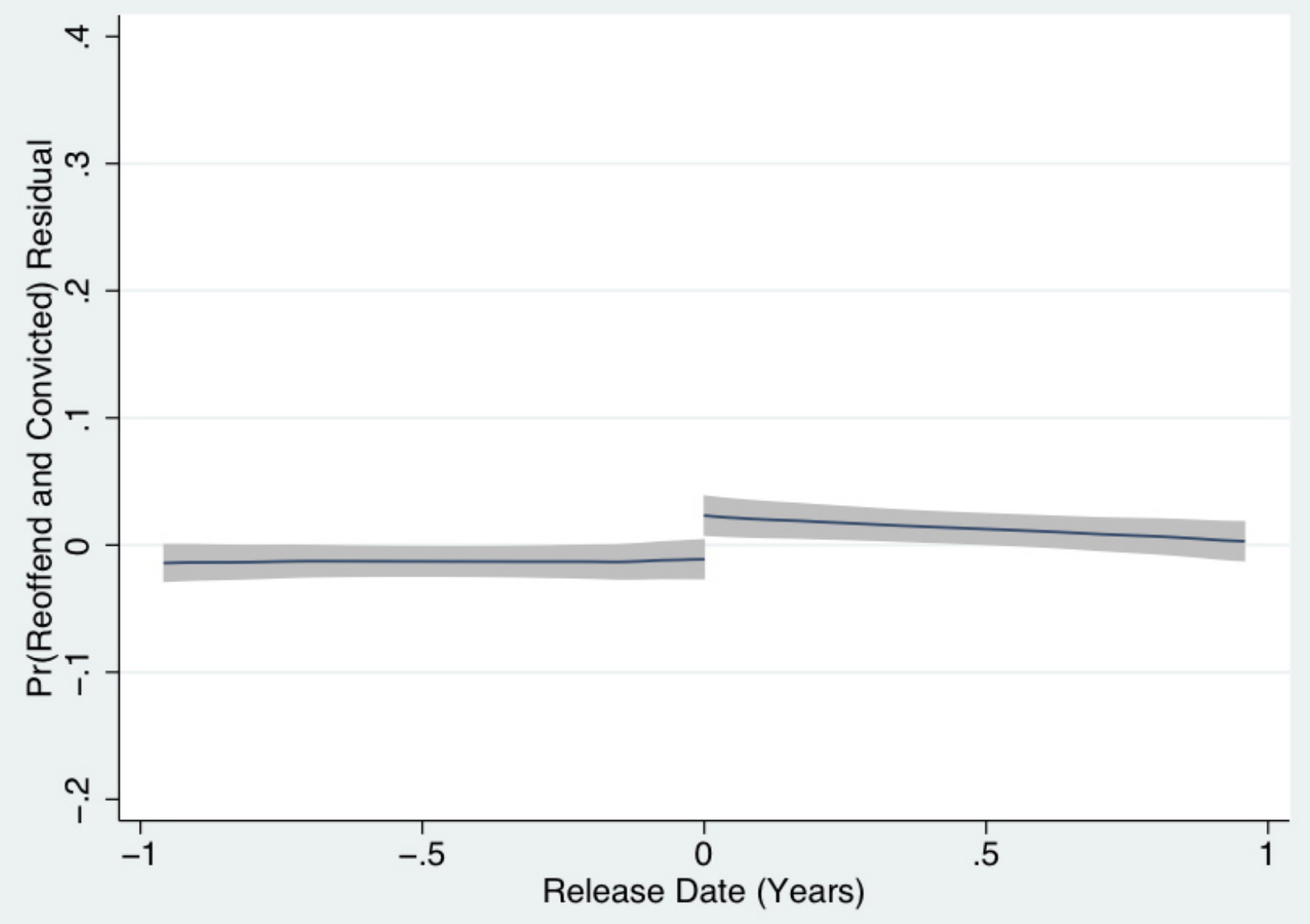

Fitted residuals from a regression of $\operatorname{Pr}$ (Reoffend and Convicted of Any Offense) on state fixed effects. Release Date $=0$ indicates the date of database expansion.

Shown with $95 \%$ confidence interval.

Sample includes all offenders.

Data source: Longitudinal administrative data from seven states' Departments of Corrections. 
Figure 3: $\operatorname{Pr}$ (Reoffend and Convicted of Any Offense), Age 25+ and First Incarceration

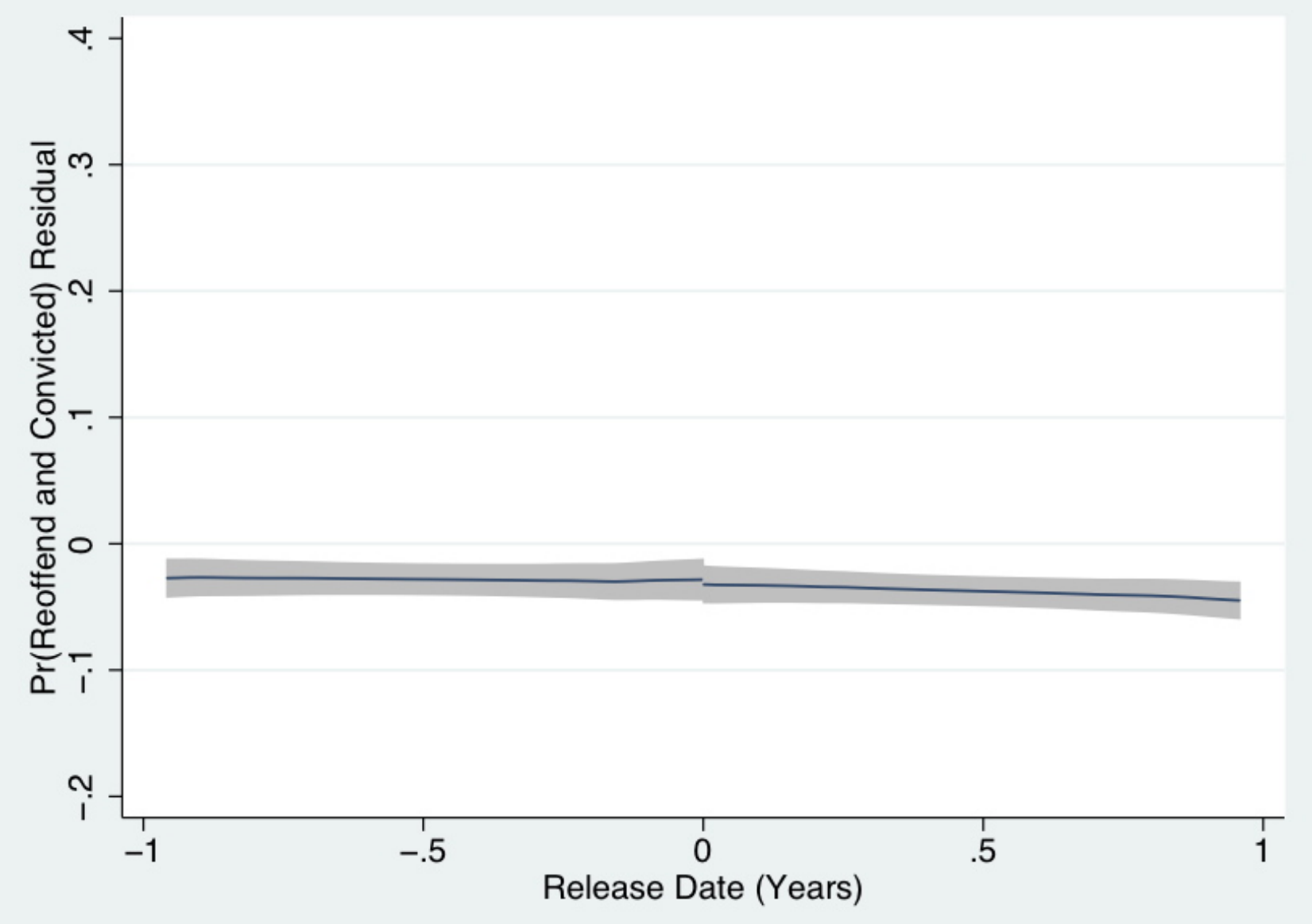

Fitted residuals from a regression of $\operatorname{Pr}$ (Reoffend and Convicted of Any Offense) on state fixed effects. Release Date $=0$ indicates the date of database expansion.

Shown with $95 \%$ confidence interval.

Sample includes offenders age 25 or older at release, with a criminal history of one conviction. Data source: Longitudinal administrative data from seven states' Departments of Corrections. 
Figure 4: $\operatorname{Pr}$ (Reoffend and Convicted of Any Offense), Age 25+ and Multiple Incarcerations

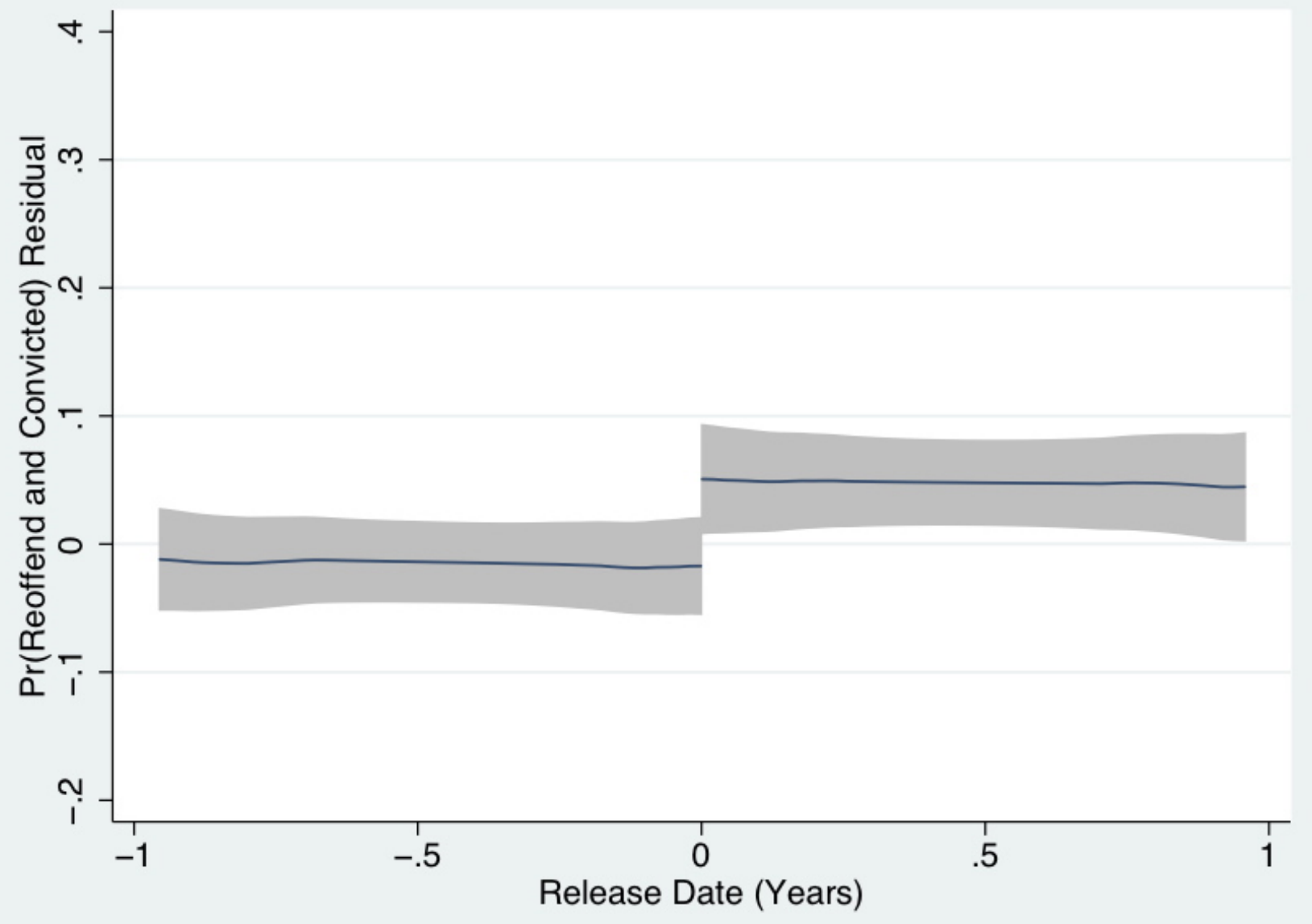

Fitted residuals from a regression of $\operatorname{Pr}$ (Reoffend and Convicted of Any Offense) on state fixed effects. Release Date $=0$ indicates the date of database expansion.

Shown with 95\% confidence interval.

Sample includes offenders age 25 or older at release, with a criminal history of multiple convictions. Data source: Longitudinal administrative data from seven states' Departments of Corrections. 
Figure 5: $\operatorname{Pr}$ (Reoffend and Convicted of Any Offense), Under 25 and First Incarceration

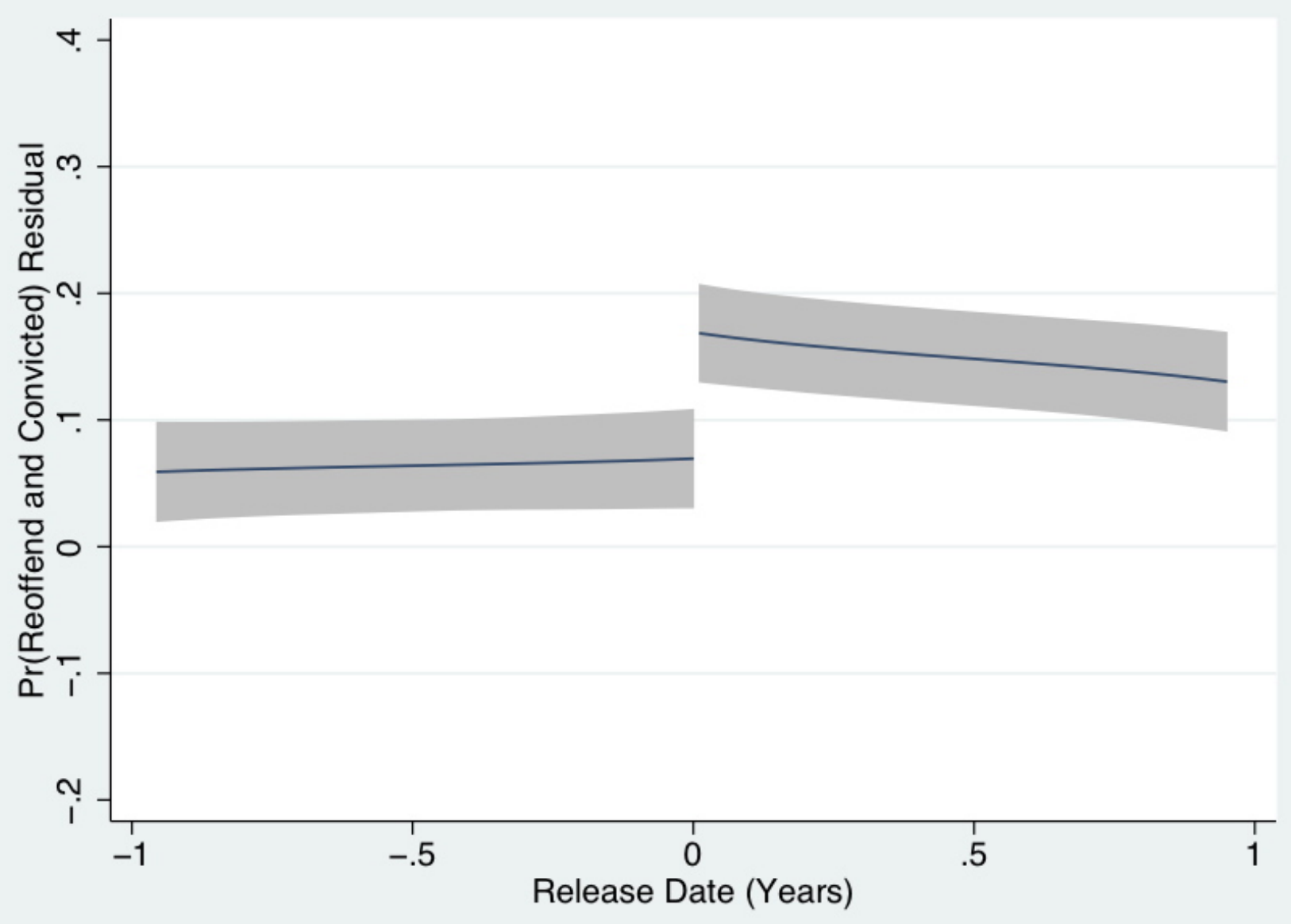

Fitted residuals from a regression of $\operatorname{Pr}$ (Reoffend and Convicted of Any Offense) on state fixed effects. Release Date $=0$ indicates the date of database expansion. Shown with $95 \%$ confidence interval.

Sample includes offenders under age 25 at release, with a criminal history of one conviction. Data source: Longitudinal administrative data from seven states' Departments of Corrections. 
Figure 6: $\operatorname{Pr}$ (Reoffend and Convicted of Any Offense), Under 25 and Multiple Incarcerations

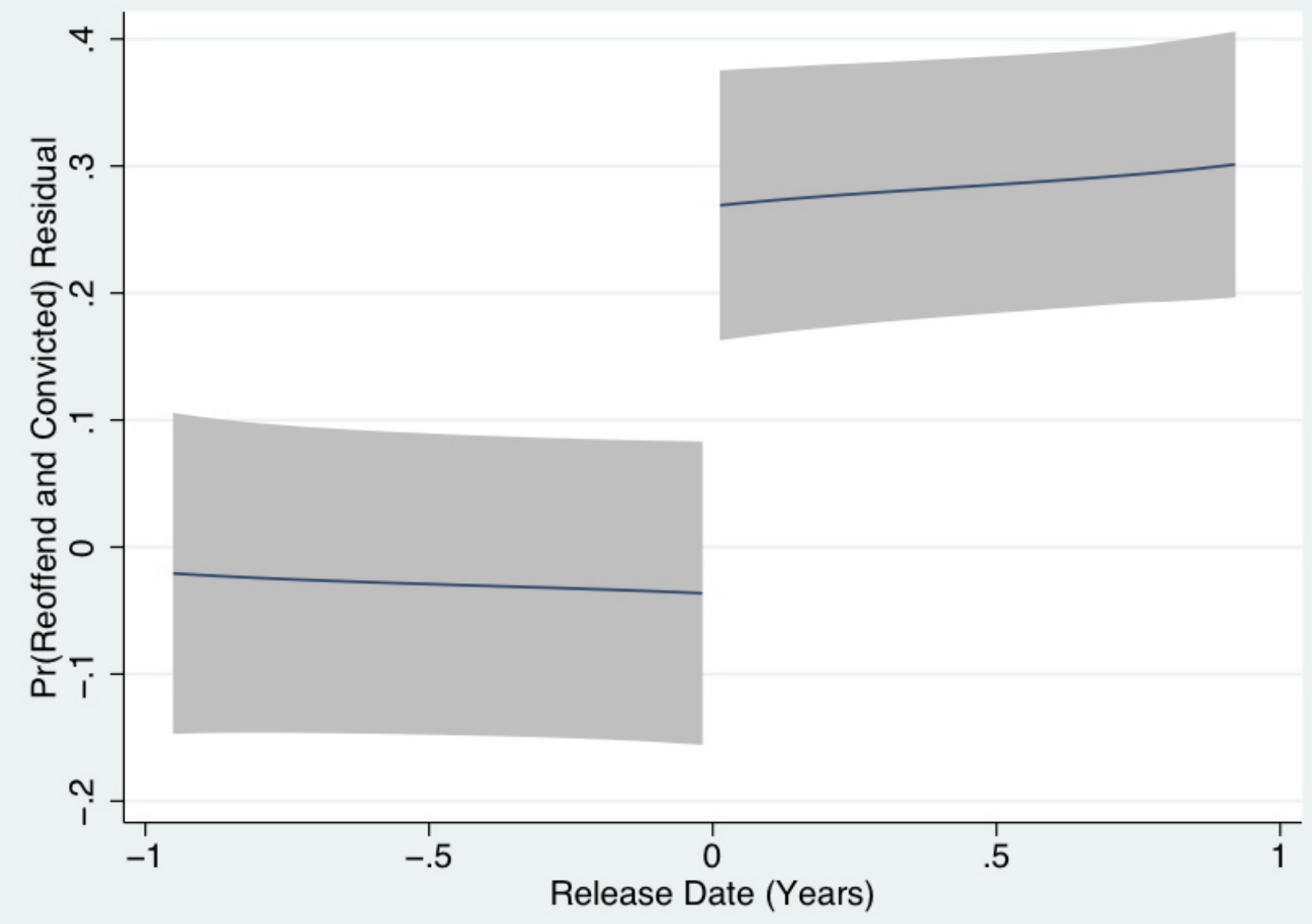

Fitted residuals from a regression of $\operatorname{Pr}$ (Reoffend and Convicted of Any Offense) on state fixed effects. Release Date $=0$ indicates the date of database expansion.

Shown with $95 \%$ confidence interval.

Sample includes offenders under age 25 at release, with a criminal history of multiple convictions. Data source: Longitudinal administrative data from seven states' Departments of Corrections. 


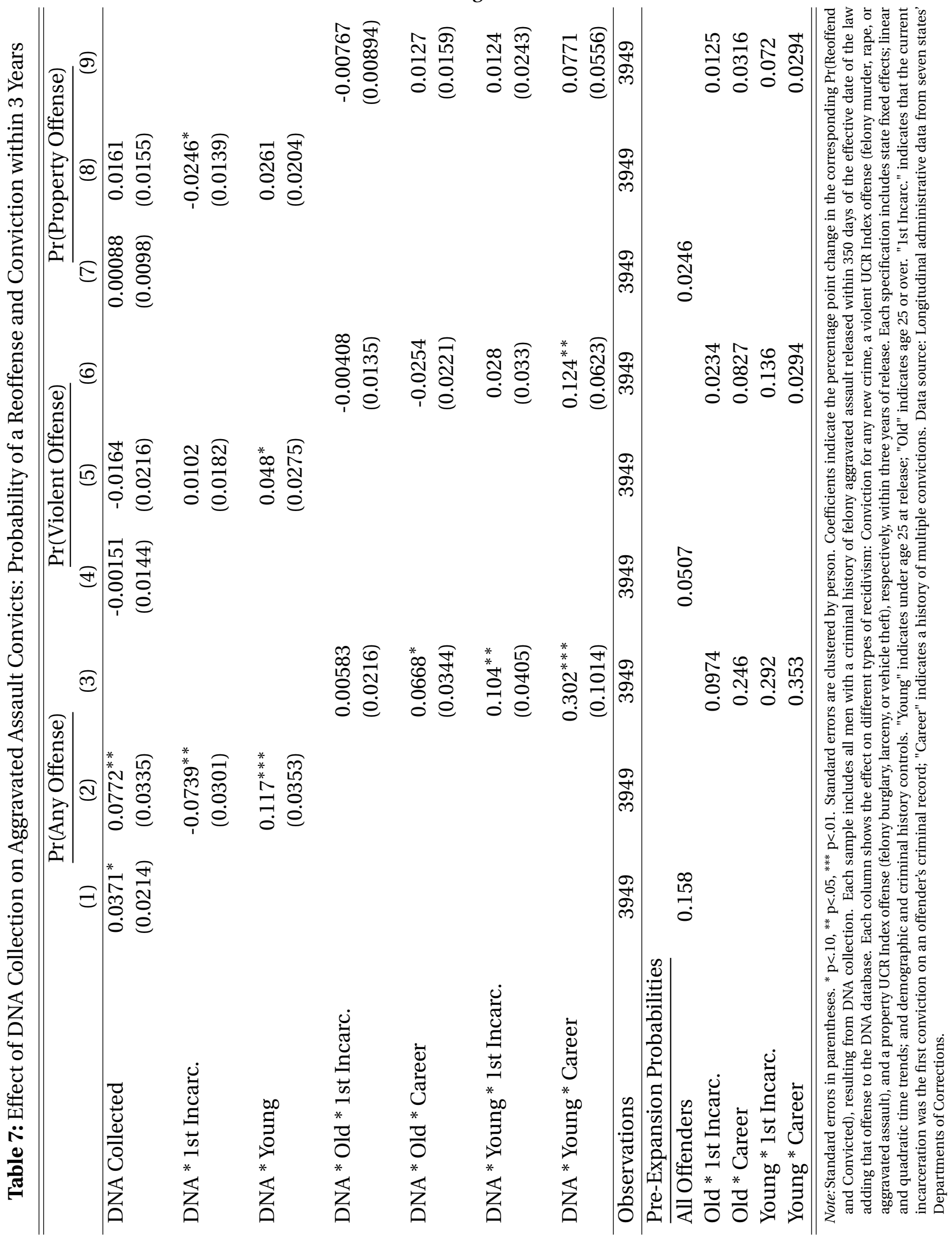




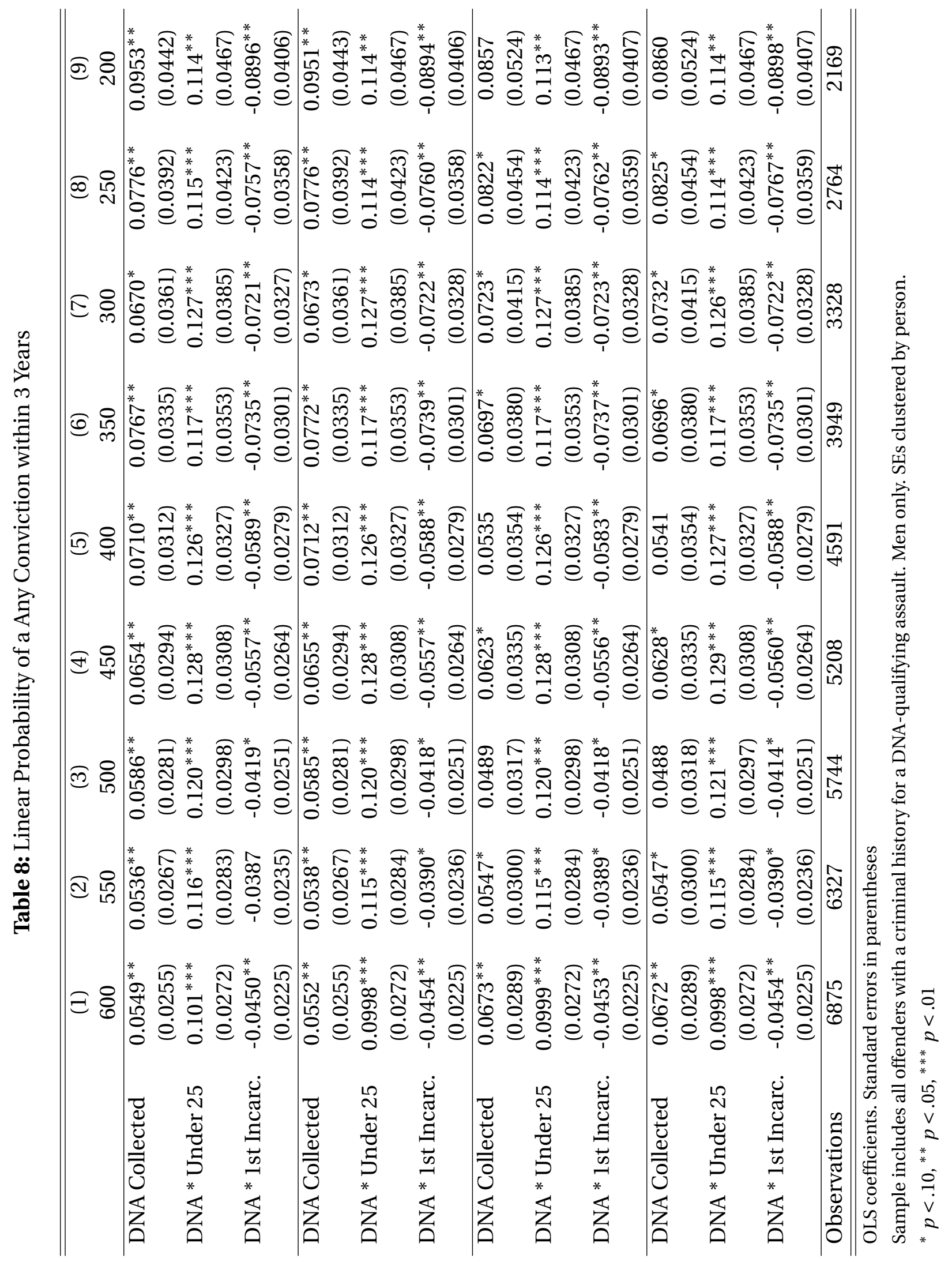




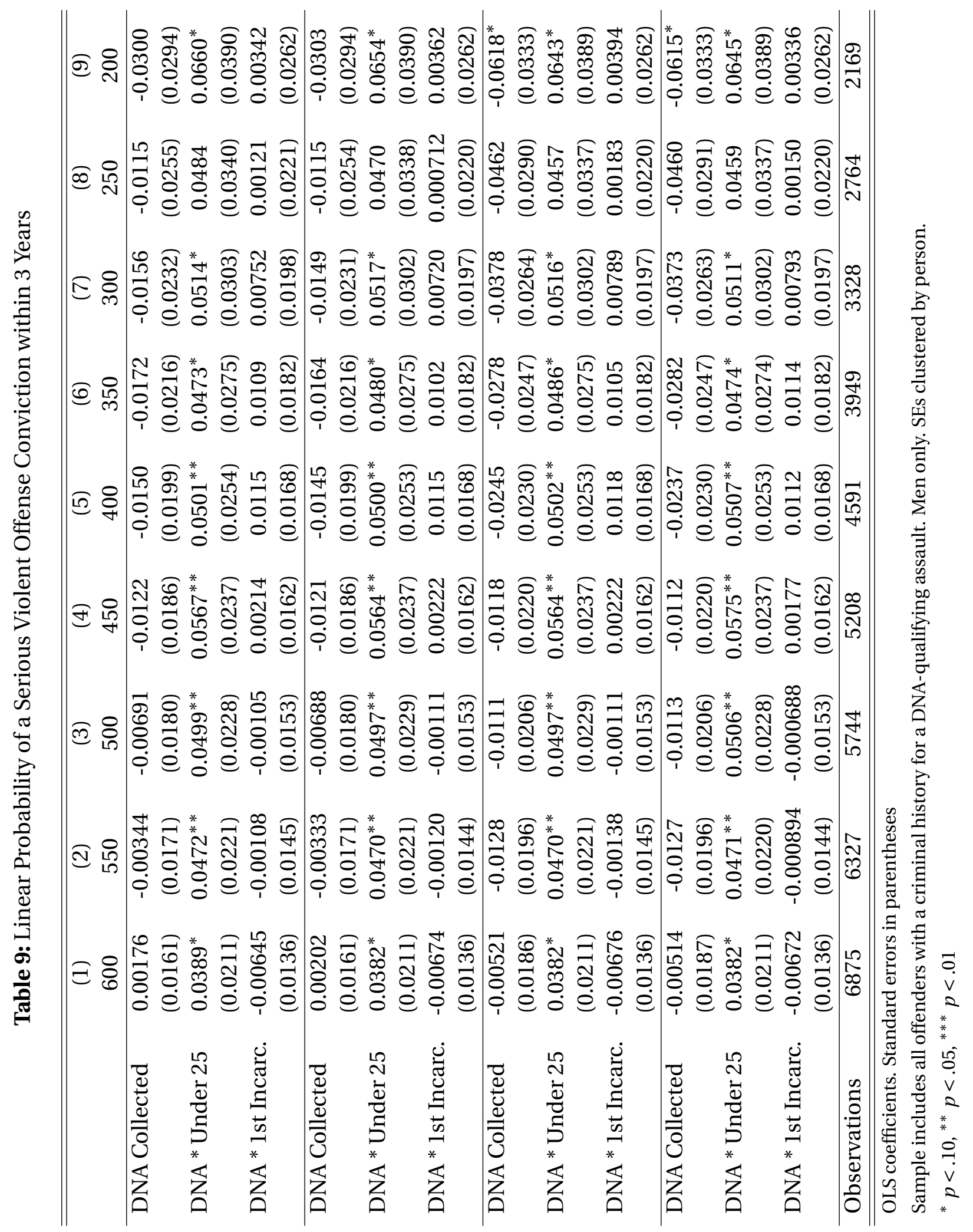




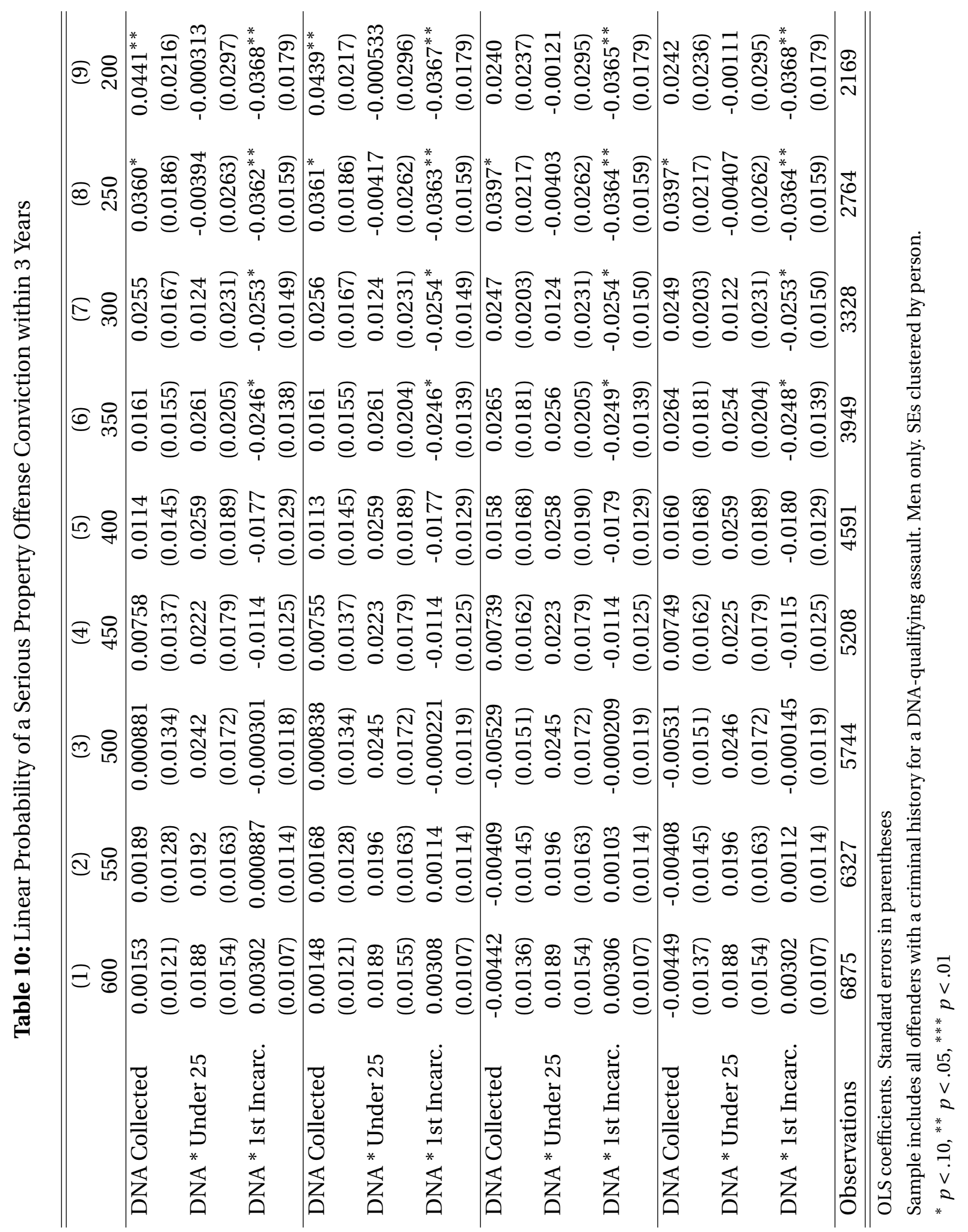




\section{Tables and Figures}

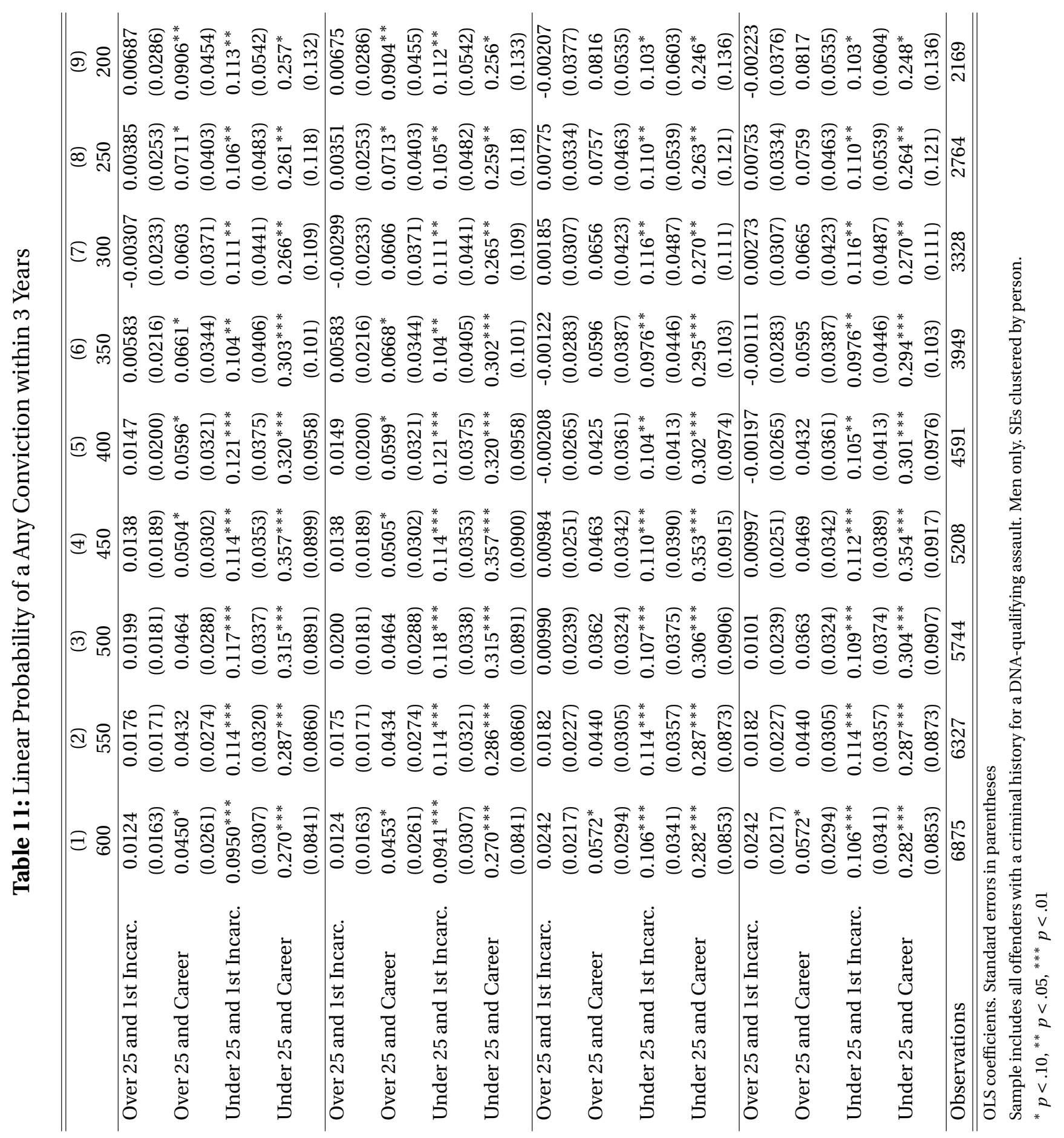




\section{Tables and Figures}

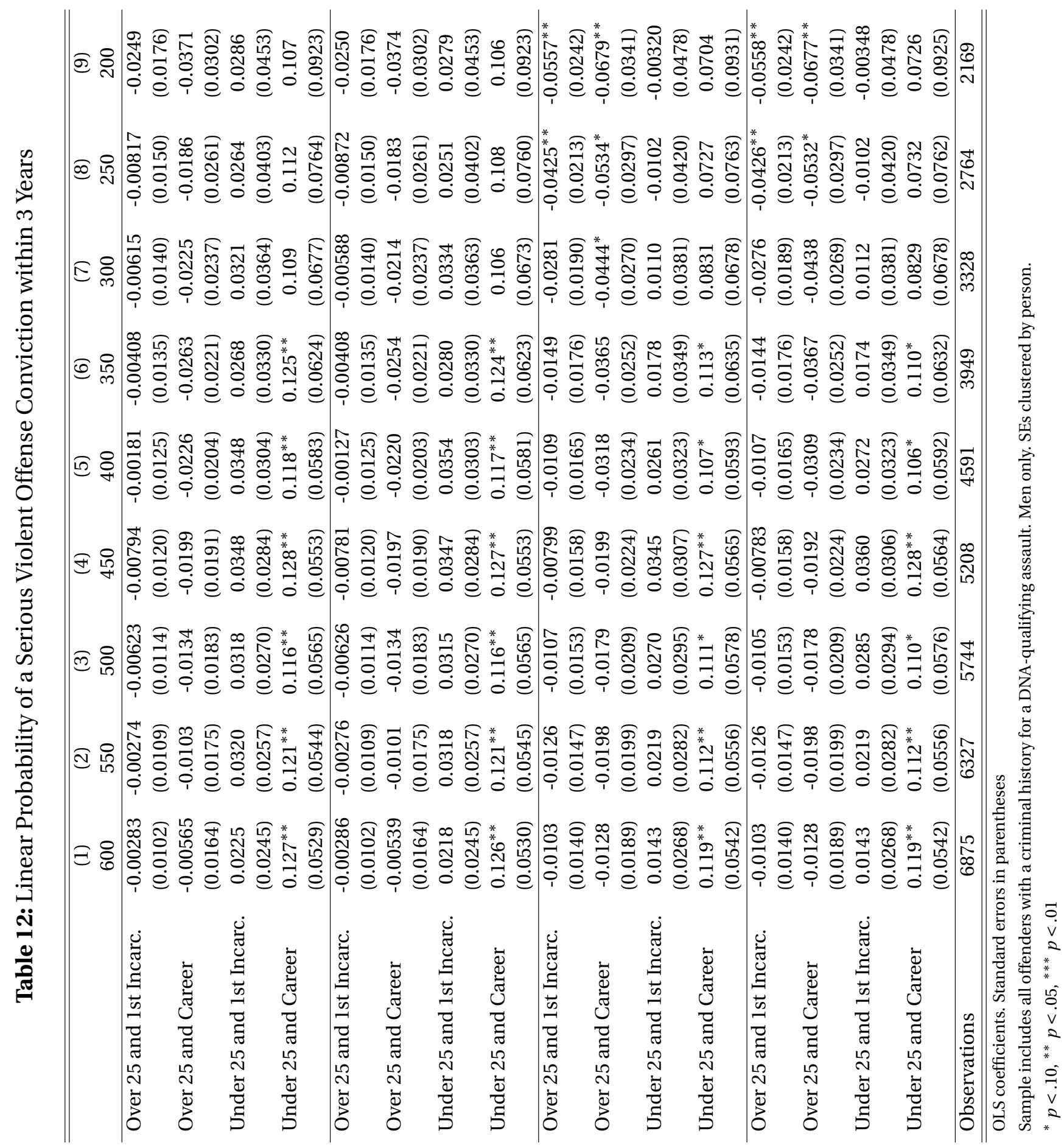




\section{Tables and Figures}

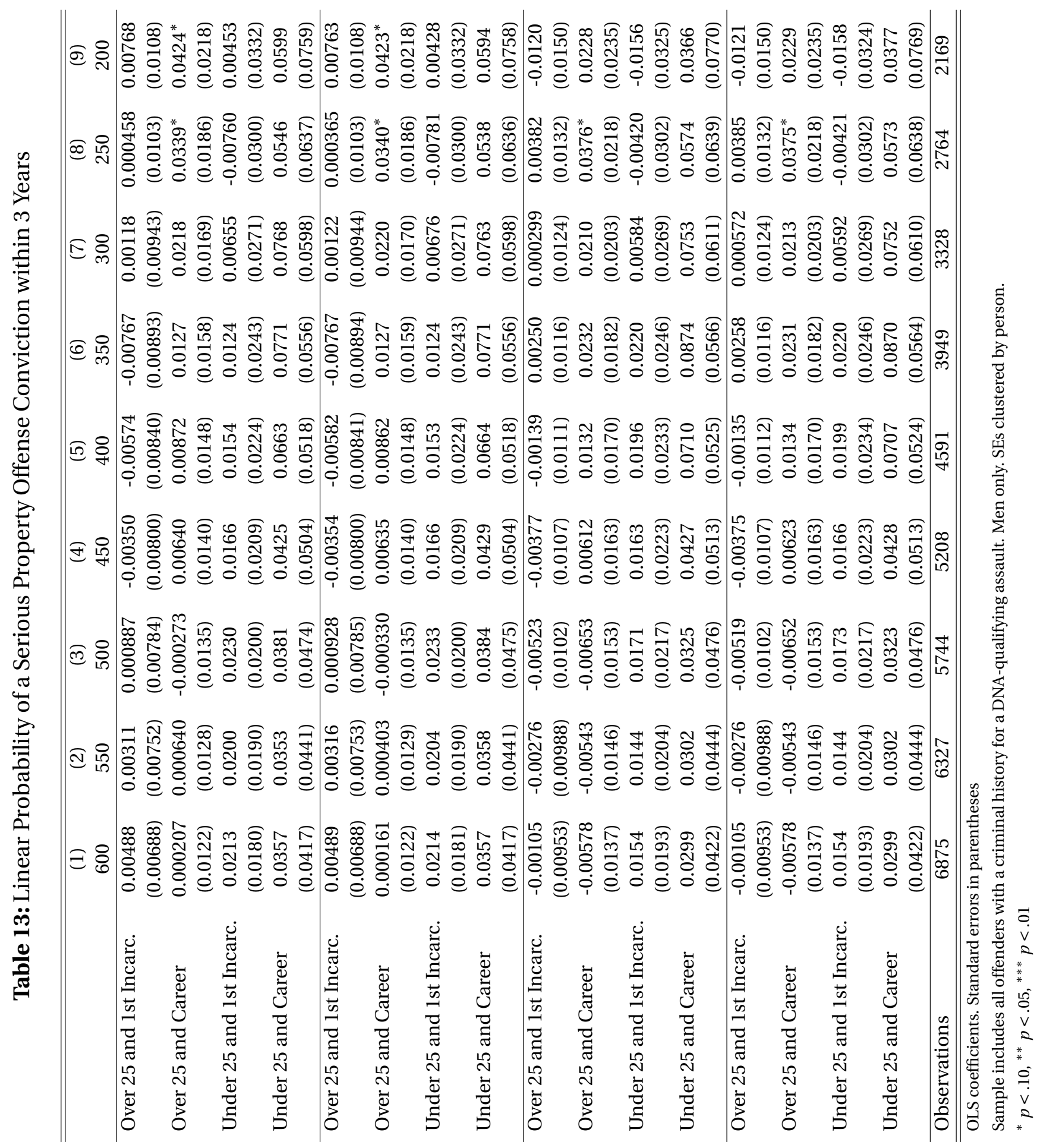


Table 14: PLACEBO TEST: Effect of DNA Collection on Aggravated Assault Convicts

\begin{tabular}{lccc}
\hline \hline & \multicolumn{3}{c}{ Linear Probability of a New Conviction within 3 years } \\
\cline { 2 - 4 } & Any Offense & Serious Violent Offense & Serious Property Offense \\
\hline DNA Collected & 0.0382 & -0.0117 & -0.00594 \\
& $(0.0334)$ & $(0.0198)$ & $(0.0179)$ \\
DNA * 1st Incarc. & 0.00387 & 0.0153 & 0.0169 \\
& $(0.0300)$ & $(0.0174)$ & $(0.0150)$ \\
DNA * Under 25 & -0.0151 & -0.0231 & 0.00502 \\
& $(0.0327)$ & $(0.0231)$ & $(0.0162)$ \\
\hline Observations & 4230 & 4230 & 4230 \\
\hline \hline
\end{tabular}

Note: Standard errors in parentheses. ${ }^{*} \mathrm{p}<.10,{ }^{* *} \mathrm{p}<.05,{ }^{* * *} \mathrm{p}<.01$. Standard errors are clustered by person. Coefficients indicate the percentage point change in the corresponding $\operatorname{Pr}($ Reoffend and Convicted), resulting from DNA collection. Each sample includes all men with a criminal history of felony aggravated assault released within 350 days of the placebo effective date of the law adding that offense to the DNA database. Placebo date is 500 days before the actual effective date. Each column shows the effect on different types of recidivism: Conviction for any new crime, a violent UCR Index offense (felony murder, rape, or aggravated assault), and a property UCR Index offense (felony burglary, larceny, or vehicle theft), respectively, within three years of release. Each specification includes state fixed effects; linear and quadratic time trends; and demographic and criminal history controls. Data source: Longitudinal administrative data from seven states' Departments of Corrections. 
Table 15: Summary Statistics: General Equilibrium Analysis

\begin{tabular}{lccccc}
\hline \hline \multicolumn{1}{c}{ Variable } & Mean & Std. Dev. & Min. & Max. & N \\
\hline Murders & 0.449 & 0.23 & 0.046 & 1.276 & 252 \\
Pr(Arrest | Murder) & 0.57 & 0.495 & 0 & 1 & 12399 \\
Rapes & 3.031 & 1.237 & 0 & 9.106 & 252 \\
Pr(Arrest | Rape) & 0.207 & 0.405 & 0 & 1 & 124422 \\
Assaults & 117.53 & 46.915 & 16.665 & 275.618 & 252 \\
Pr(Arrest | Assault) & 0.484 & 0.500 & 0 & 1 & 768802 \\
Robberies & 10.143 & 5.652 & 0.659 & 24.923 & 252 \\
Pr(Arrest | Robbery) & 0.189 & 0.392 & 0 & 1 & 296372 \\
Burglaries & 61.333 & 24.438 & 18.699 & 116.728 & 252 \\
Pr(Arrest | Burglary) & 0.112 & 0.316 & 0 & 1 & 2195934 \\
Larcenies & 209.463 & 58.776 & 76.636 & 349.014 & 252 \\
Pr(Arrest | Larceny) & 0.150 & 0.357 & 0 & 1 & 8362145 \\
Vehicle Thefts & 31.298 & 16.072 & 7.431 & 100.349 & 252 \\
Pr(Arrest | Vehicle Theft) & 0.098 & 0.297 & 0 & 1 & 919947 \\
\hline Sex Offenses: Year Added & 1994.3 & 2.8 & 1988 & 1999 & 252 \\
Violent Offenses: Year Added & 1996.7 & 3.6 & 1989 & 2005 & 252 \\
Burglary: Year Added & 2000.9 & 3.6 & 1990 & 2009 & 252 \\
All felonies: Year Added & 2002.5 & 3.7 & 1990 & 2009 & 230 \\
\hline Police Officers & 17.279 & 5.472 & 8.714 & 33.314 & 252 \\
\hline DNA Profiles, 2000 & 25.916 & 38.823 & 0.357 & 190.473 & 22 \\
DNA Profiles, 2001 & 32.976 & 47.119 & 2.194 & 234.962 & 22 \\
DNA Profiles, 2002 & 50.737 & 53.779 & 5.182 & 256.386 & 23 \\
DNA Profiles, 2003 & 54.86 & 47.244 & 0.094 & 273.335 & 47 \\
DNA Profiles, 2004 & 68.855 & 64.064 & 2.042 & 305.014 & 25 \\
DNA Profiles, 2005 & 87.38 & 72.303 & 3.756 & 319.962 & 27 \\
DNA Profiles, 2006 & 137.49 & 95.936 & 8.758 & 335.921 & 21 \\
DNA Profiles, 2007 & 168.433 & 94.962 & 12.055 & 349.375 & 19 \\
DNA Profiles, 2008 & 177.723 & 85.39 & 21.303 & 377.826 & 46 \\
DNA Profiles, All Years & 92.795 & 87.836 & 0.094 & 377.826 & 252 \\
\hline Note: Crime, police and DNA profile statistics are per 10,000 residents. & & & \\
& & & & & \\
\hline
\end{tabular}


Table 16: Effect of DNA Database Size on Crime Rates

\begin{tabular}{lccc}
\hline \hline & \multicolumn{2}{c}{ Effect of 1 SD increase in DNA profiles } & \multirow{2}{*}{$\begin{array}{c}\text { Implied change if add } \\
\text { serious felony arrestees }\end{array}$} \\
\cline { 2 - 3 } & OLS & Simulated IV & $-3.2 \%$ \\
\hline Murder Rate & -0.00886 & $-0.261^{* *}$ & $-6.6 \%$ \\
& $(0.0593)$ & $(0.121)$ & $-2.9 \%$ \\
\hline Rape Rate & -0.0846 & $-0.659^{* * *}$ & \\
& $(0.103)$ & $(0.158)$ & $0.4 \%$ \\
\hline Assault Rate & -0.0494 & $-0.301^{* * *}$ & $-1.2 \%$ \\
& $(0.0674)$ & $(0.108)$ & $-2.9 \%$ \\
\hline Burglary Rate & 0.0187 & 0.0248 & \\
\hline Larceny Rate & $(0.0315)$ & $(0.0736)$ & $-5.4 \%$ \\
& $(0.00553$ & -0.124 & \\
\hline Vehicle Theft Rate & $-0.0986)$ & $(0.120)$ & \\
\hline Observations & $(0.0846)$ & $-0.423^{* *}$ & $(0.212)$ \\
\hline \hline
\end{tabular}

Note: Standardized beta coefficients; standardized standard errors in parentheses. ${ }^{*} \mathrm{p}<.10,{ }^{* *} \mathrm{p}<.05,{ }^{* * *} \mathrm{p}<.01$. Each coefficient indicates the change in the corresponding number of crimes reported (per resident), in standard deviations, resulting from a one standard deviation increase in the number of DNA profiles (per resident) in the state database. Instrumental variables are the simulated stock and flow of qualifying offenders. Both specifications include a time trend and state fixed effects. Standard errors are clustered by state. Crime rate data source: FBI UCR. 
Table 17: Effect of DNA Profiles on the Probability of Arresting a Suspect in New Crimes

\begin{tabular}{|c|c|c|c|}
\hline & \multicolumn{2}{|c|}{ Effect of 1 SD increase in DNA profiles } & \multirow{2}{*}{$\begin{array}{l}\text { Implied change if add } \\
\text { serious felony arrestees }\end{array}$} \\
\hline & OLS & Sim IV & \\
\hline \multirow[t]{2}{*}{ Murder } & $-0.221^{* * *}$ & $-0.493^{* * *}$ & $-10.4 \%$ \\
\hline & $(0.0318)$ & $(0.0711)$ & \\
\hline$N$ & 12399 & 12399 & \\
\hline \multirow[t]{2}{*}{ Rape } & $-0.0208^{* *}$ & -0.0219 & $-1.0 \%$ \\
\hline & $(0.00834)$ & $(0.0151)$ & \\
\hline$N$ & 124422 & 124422 & \\
\hline \multirow[t]{2}{*}{ Assault } & $-0.0873^{* * *}$ & $-0.0954^{* * *}$ & $-2.4 \%$ \\
\hline & $(0.00336)$ & $(0.00577)$ & \\
\hline$N$ & 768802 & 768802 & \\
\hline \multirow[t]{2}{*}{ Robbery } & $-0.0500^{* * *}$ & $-0.0598^{* * *}$ & $-3.0 \%$ \\
\hline & $(0.00571)$ & $(0.0129)$ & \\
\hline$N$ & 296372 & 296372 & \\
\hline \multirow[t]{2}{*}{ Burglary } & $-0.0272^{* * *}$ & $-0.0276^{* * *}$ & $-1.9 \%$ \\
\hline & $(0.00209)$ & $(0.00429)$ & \\
\hline$N$ & 2195934 & 2195934 & \\
\hline \multirow[t]{2}{*}{ Larceny } & $-0.0210^{* * *}$ & $-0.00981^{* * *}$ & $-0.6 \%$ \\
\hline & $(0.00114)$ & $(0.00225)$ & \\
\hline$N$ & 8362145 & 8362145 & \\
\hline \multirow[t]{2}{*}{ Vehicle Theft } & $-0.0184^{* * *}$ & $-0.0201^{* * *}$ & $-1.5 \%$ \\
\hline & $(0.00322)$ & $(0.00614)$ & \\
\hline$N$ & 919947 & 919947 & \\
\hline
\end{tabular}

Note: Standardized beta coefficients; standardized standard errors in parentheses. ${ }^{*} \mathrm{p}<.10,{ }^{* *} \mathrm{p}<.05,{ }^{* * *} \mathrm{p}<.01$. Standard errors are clustered by state. Each coefficient indicates the change in the corresponding Pr(Arrest Suspect), resulting from an increase in the number of DNA profiles (per resident) in the state database. Instrumental variables are the simulated stock and flow of qualifying offenders. Specification includes a time trend and jurisdiction fixed effects. Arrest probability data source: FBI NIBRS. 


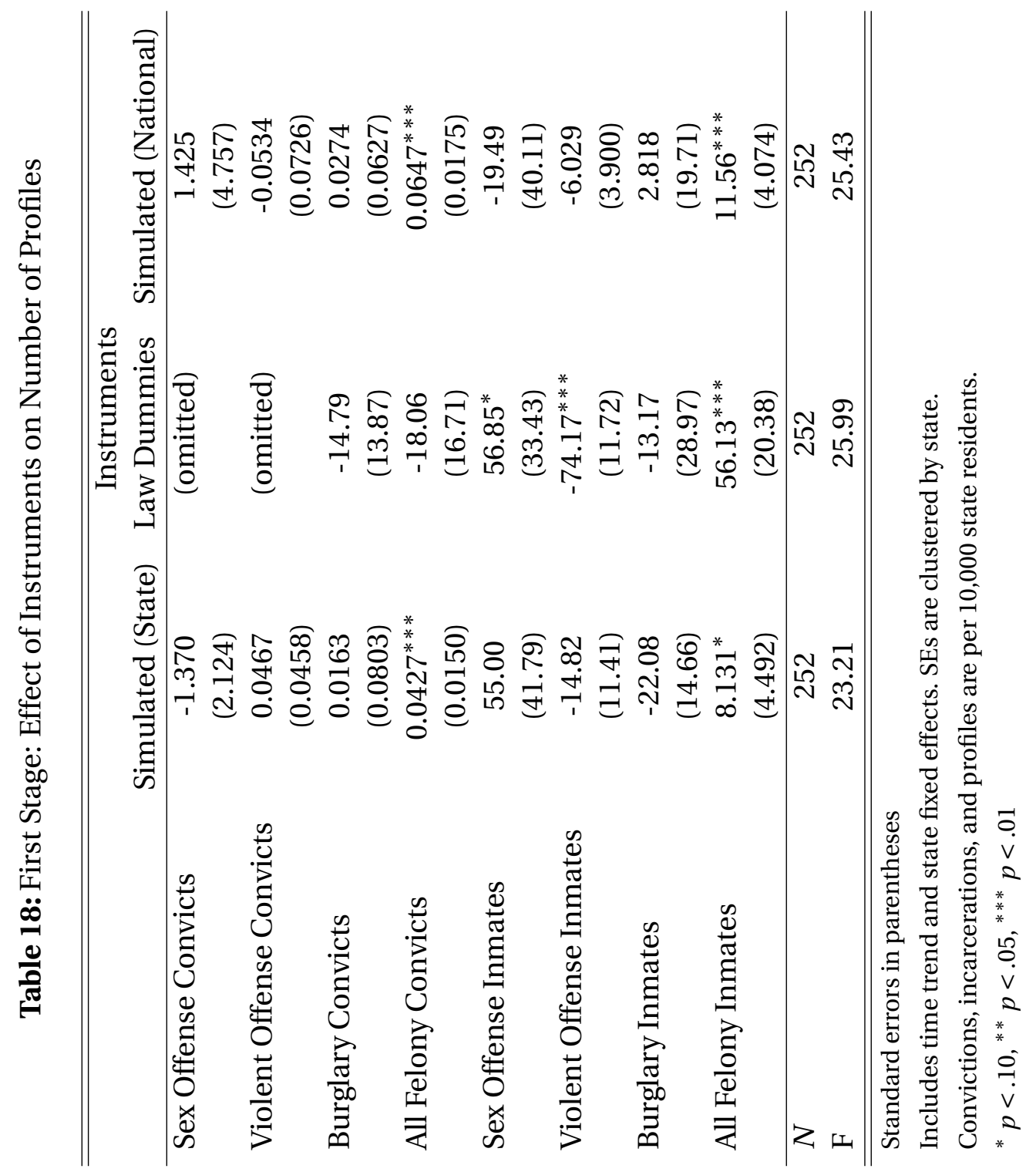




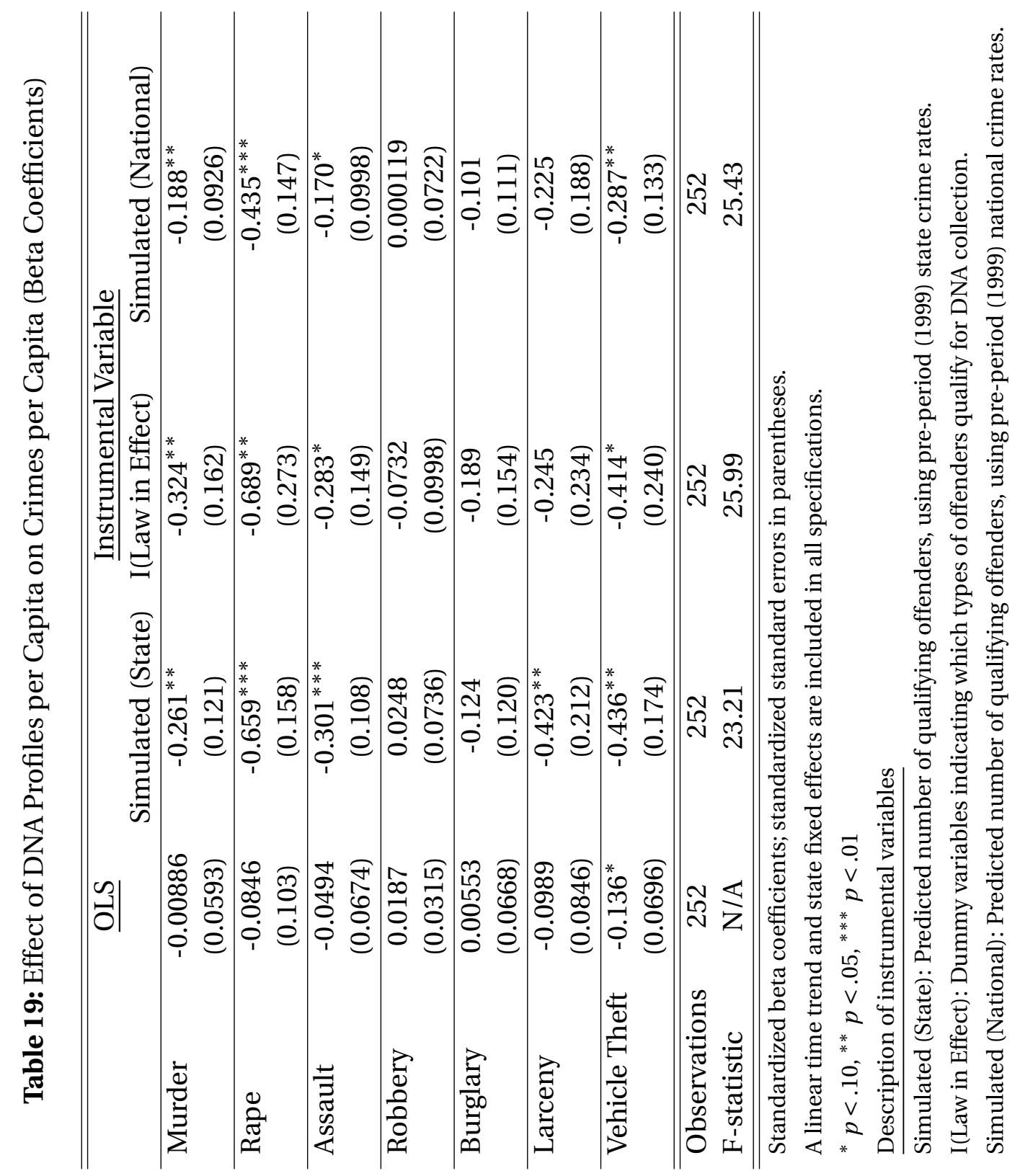




\section{Tables and Figures}

Table 20: Effect of DNA Database Size on Crime Rates, Controlling for Police

\begin{tabular}{|c|c|c|c|}
\hline & \multicolumn{2}{|c|}{ Effect of 1 SD increase in DNA profiles } & \multirow{2}{*}{$\begin{array}{l}\text { Implied change if add } \\
\text { serious felony arrestees }\end{array}$} \\
\hline & OLS & Simulated IV & \\
\hline \multirow[t]{2}{*}{ Murder Rate } & -0.00854 & $-0.261^{* *}$ & $-3.2 \%$ \\
\hline & $(0.0600)$ & $(0.126)$ & \\
\hline \multirow[t]{2}{*}{ Rape Rate } & -0.0813 & $-0.642^{* * *}$ & $-6.4 \%$ \\
\hline & $(0.104)$ & $(0.168)$ & \\
\hline \multirow[t]{2}{*}{ Assault Rate } & -0.0457 & $-0.273^{* *}$ & $-2.6 \%$ \\
\hline & $(0.0665)$ & $(0.112)$ & \\
\hline \multirow[t]{2}{*}{ Robbery Rate } & 0.0181 & 0.0212 & $0.3 \%$ \\
\hline & $(0.0319)$ & $(0.0753)$ & \\
\hline \multirow[t]{2}{*}{ Burglary Rate } & 0.00754 & -0.109 & $-1.1 \%$ \\
\hline & $(0.0671)$ & $(0.123)$ & \\
\hline \multirow[t]{2}{*}{ Larceny Rate } & -0.0965 & $-0.410^{* *}$ & $-2.8 \%$ \\
\hline & $(0.0850)$ & $(0.209)$ & \\
\hline \multirow[t]{2}{*}{ Vehicle Theft Rate } & $-0.131^{*}$ & $-0.395^{* *}$ & $-4.9 \%$ \\
\hline & $(0.0693)$ & $(0.168)$ & \\
\hline Observations & 252 & 252 & \\
\hline
\end{tabular}

Note: Standardized beta coefficients; standardized standard errors in parentheses. ${ }^{*} \mathrm{p}<.10,{ }^{* *} \mathrm{p}<.05,{ }^{* * *} \mathrm{p}<.01$. Standard errors are clustered by state. Each coefficient indicates the change in the corresponding number of crimes reported (per resident), in standard deviations, resulting from a one standard deviation increase in the number of DNA profiles (per resident) in the state database. Instrumental variables are the simulated stock and flow of qualifying offenders. Specifications include a time trend, state fixed effects, and the number of police officers per capita. Crime rate data source: FBI UCR. 
9 Tables and Figures

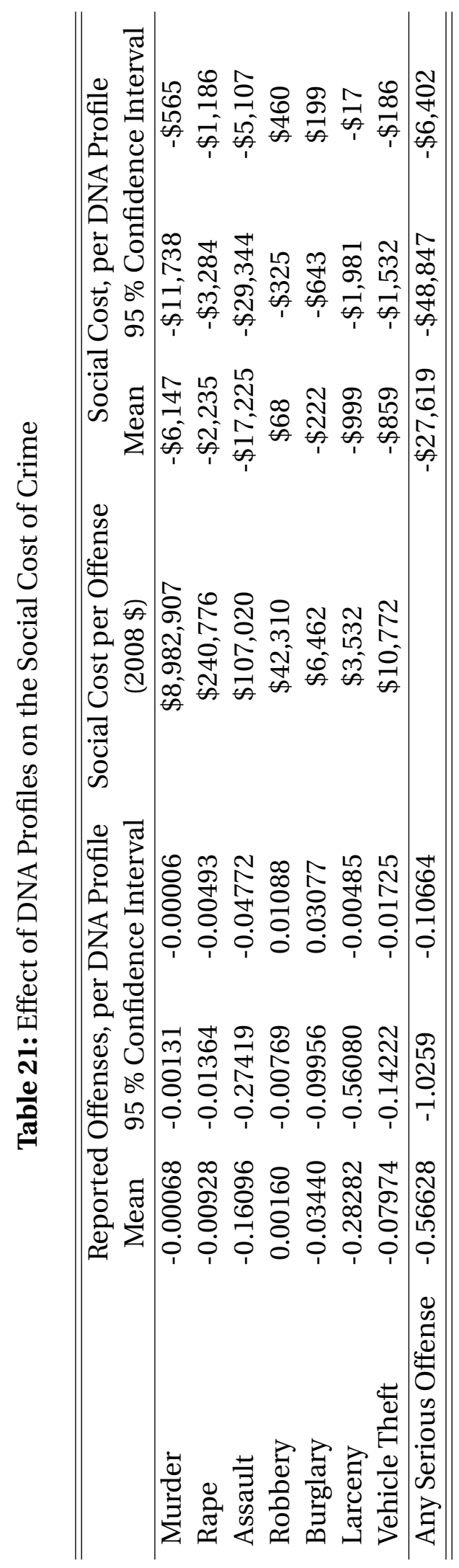




\section{Tables and Figures}

Table 22: Effect of DNA Database Size on Incarceration Rates

\begin{tabular}{lcc}
\hline \hline & $(1)$ & $(2)$ \\
& OLS & Sim IV \\
\hline Incarceration Rate & -0.0314 & -0.1000 \\
& $(0.0321)$ & $(0.0882)$ \\
\hline Observations & 252 & 252 \\
\hline \hline Note: Standardized beta coefficients; standardized standard \\
errors in parentheses. * p $<$.10, $^{* * *}$ p $<$.05, ${ }^{* * *}$ p $<$.01. Standard \\
errors are clustered by state. Each coefficient indicates the \\
change in the corresponding number of incarcerated in- \\
mates (per resident), in standard deviations, resulting from \\
a one standard deviation increase in the number of DNA \\
profiles (per resident) in the state database. Instrumental \\
variables are the simulated stock and flow of qualifying \\
offenders. Specifications include a time trend and state \\
fixed effects. Incarceration rate data source: BJS.
\end{tabular}

